
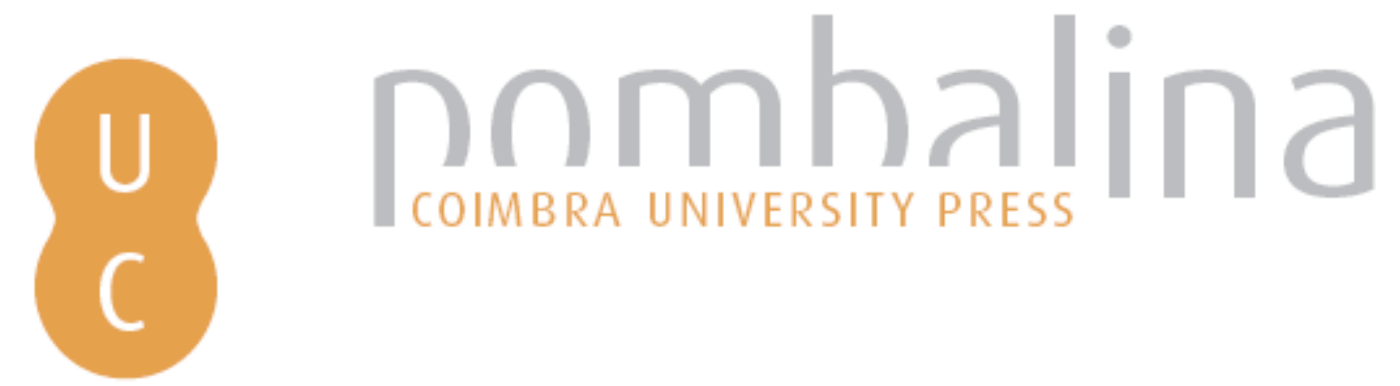

\title{
A descrição camoniana da europa e a cartografia ginecomórfica
}

Autor(es): $\quad$ Pinho, Sebastião Tavares de

Publicado por: Imprensa da Universidade de Coimbra

URL

persistente: URI:http://hdl.handle.net/10316.2/31469

DOI: $\quad$ DOI:http://dx.doi.org/10.14195/978-989-26-0569-2_18

Accessed : $\quad$ 26-Apr-2023 15:45:35

A navegação consulta e descarregamento dos títulos inseridos nas Bibliotecas Digitais UC Digitalis, UC Pombalina e UC Impactum, pressupõem a aceitação plena e sem reservas dos Termos e Condições de Uso destas Bibliotecas Digitais, disponíveis em https://digitalis.uc.pt/pt-pt/termos.

Conforme exposto nos referidos Termos e Condições de Uso, o descarregamento de títulos de acesso restrito requer uma licença válida de autorização devendo o utilizador aceder ao(s) documento(s) a partir de um endereço de IP da instituição detentora da supramencionada licença.

Ao utilizador é apenas permitido o descarregamento para uso pessoal, pelo que o emprego do(s) título(s) descarregado(s) para outro fim, designadamente comercial, carece de autorização do respetivo autor ou editor da obra.

Na medida em que todas as obras da UC Digitalis se encontram protegidas pelo Código do Direito de Autor e Direitos Conexos e demais legislação aplicável, toda a cópia, parcial ou total, deste documento, nos casos em que é legalmente admitida, deverá conter ou fazer-se acompanhar por este aviso. 
Sebastião Tavares de Pinho

Universidade de Coimbra

\section{A DESCRIÇÃO CAMONIANA DA EUROPA E A CARTOGRAFIA GINECOMÓRFICA1}

Eis aqui, quási cume da cabeça

De Europa toda, o Reino Lusitano.

(Camões, Lus. III, 20, 1-2)

Uma das marcas de maior evidência no estilo da epopeia camoniana é o carácter visualista de grande parte do seu discurso narrativo e, em particular, de algumas das suas frequentes e amplas descriçôes. Tal feição é explicitamente denunciada pela repetida presença de léxico demonstrativo sob a forma de pronomes, adjectivos, advérbios e partículas de função eminentemente díctica, e sobretudo pela acumulação de verbos de sentido visual como "ver", "olhar" e mesmo "atentar", que aparecem, no seu conjunto, perto de cento e cinquenta vezes, por exemplo, só no espaço, embora longo, concedido pelo Poeta ao texto descritivo e explicativo de Paulo da Gama acerca das figuras das bandeiras da capitaina, no canto VIII d'Os Lusíadas, perante e a pedido do Catual; bem como na descrição da "Máquina do Mundo" e da geografia das novas terras descobertas, que ocupa quase toda a segunda metade do último canto do poema.

São, com efeito, variadas as fórmulas enunciativas com que o irmão de Vasco da Gama enumera e descreve os vinte e cinco vultos pintados naqueles estandartes e, com eles, grande parte da história portuguesa, desde os primórdios legendários de Luso e Ulisses, passando por Viriato, Sertório, pelo conde D. Henrique e pelo primeiro rei português, até aos infantes D. Pedro e D. Henrique e aos dois Meneses, D. Pedro e D. Duarte:

Este que vês é Luso [...]. (VIII, 2, 7)

1 Texto apresentado na Faculdade de Letras da Universidade de Coimbra no dia 16 de Abril de 1996, durante a VI Reunião Internacional de Camonistas, e publicado pela primeira vez na Revista Camoniana, $3^{\text {a }}$ série, vol. 14, Bauru, São Paulo, 2003, p. 185-243, com a actualização de algumas referências bibliográficas, entretanto saídas a público. 
Vês outro, que [...] Ulisses é. (VIII, 4, 5; 5, 1)

Este que vês, [...] /

Viriato sabemos que se chama. (VIII, 6, 2-3)

Outro está aqui que, contra a pátria irosa, /

Degradado, connosco se alevanta. (VIII, 7, 5-6)

Vês [...] Olha tão sotis artes e maneiras / [...]

Ele é Sertório. (VIII, 8, 1-5-8)

Olha estoutra bandeira, e vê pintado /

O grão progenitor dos Reis primeiros. (VIII, 9, 1-2)

Este é o primeiro Afonso (disse o Gama). (VIII, 11, 1)

Este é aquele zeloso a quem Deus ama. (VIII, 11, 5)

Egas Moniz se chama o forte velho / [...]

Vê-lo cá vai cos filhos a entregar-se. (VIII, 13, 7; 14, 1)

Vês este que $[\ldots] /$

Vê-lo cá vai pintado nesta armada / [...]

É Dom Fuas Roupinho. (VIII, 16, 1 e 5; 17, 1)

Olha Henrique, famoso cavaleiro. (VIII, 18, 5).

Enfim, expressóes como "Mas vê", "Mas olha", "Não vês", "Mas não vês", "Atenta”, e muitas outras, desdobram-se por cerca de meio cento, ao longo das quarenta e quatro estrofes que compóem aquela exposição de Paulo da Gama perante o alto dignitário de Calecut.

$\mathrm{Na}$ apresentação da Máquina do Mundo do Canto X que, em miniatura, a deusa Tétis revela ao Jasão Português e seus companheiros após o banquete da Ilha Namorada, são as mesmas fórmulas, ou outras equivalentes, de que ela se serve para a descrever. A linguagem díctica e visualista aparece logo a partir do primeiro verso da estrofe 80 ,

Vês aqui a grande máquina do Mundo,

Etérea e elemental, que fabricada $[\ldots] \quad(\mathrm{X}, 80,1-2)$

e continua em toda a explicação das catorze esferas que compóem aquele sistema geocêntrico da constituição do universo:

Este orbe que, primeiro, vai cercando /

Os outros [...] / Empíreo se nomeia [...]. (X, 81, 1-2 e 5)

Aqui, só verdadeiros, gloriosos /

Divos estâo [...]. (X, 82, 1-2) 
Quer logo aqui a pintura [...]. (X, 84, 1)

Debaxo deste círculo, onde as mundas /

Almas divinas gozam [...]. (X, 85, 5-6)

Debaxo deste leve, anda outro lento. (X, 86, 5)

Olha estoutro debaxo, que [...] /

Bem vês como se veste e faz tornado. (X, 87,1 e 5)

Exemplo de particular apelo ao sentido da vista é a estrofe seguinte, em que o Poeta aponta, na sequência da descriçáo do zodíaco, algumas das suas constelaçóes:

Olha, por outras partes, a pintura

Que as estrelas fulgentes vão fazendo:

Olha a Carreta, atenta a Cinosura,

Andrómeda e seu pai, e o Drago horrendo.

Vê de Cassiopeia a fermosura

E do Orionte o gesto turbulento;

Olha o Cisne morrendo que sospira,

A Lebre e os Cães, a Nau e a doce Lira. (X, 88, 1-8)

Atingido o interior deste sistema ptolemaico, que é a Terra - "Neste centro, pousada dos humanos" (X, 91, 1) -, inicia Tétis a longa descrição do espaço geográfico por onde os lusitanos "Feitos farão tão dinos de memória, / Que não caibam em verso ou larga glória” (X, 71,7-8). Nele, a deusa marinha faz, por mercê da "Sapiência Suprema”, com que o Gama veja "cos olhos corporais" [...] "o que náo pode a vã ciência / Dos errados e míseros mortais" (X, 76, 1-4) e leva-o a contemplar de visu, numa demorada e profética antevisão, a história dos descobrimentos portugueses durante os próximos setenta anos, ao longo da superfície da Terra, partindo da Europa e estendendo-se pelos novos mundos até ao Extremo Oriente, numa sugestiva exposição audiovisual, como se fora na presença de um mapa-múndi oferecido por aquele misterioso globo. Aqui, assistimos de novo ao recurso à dimensão presencial e visualista e à forma díctica e locativa do discurso:

Vês a Europa Cristã, [...] / Vês a África, [...] / Olha essa terra toda, [...] (X, 92, 1, 3 e 7); Vê do Benomopata o grande império [...] / Vê que do lago donde se derrama / O Nilo, [...] (X, 93, 1 e 7-8); Olha as casas dos Negros, como estão / [...] Olha deles a bruta multidão (X, 94, 1 e 5); Olha lá as alagoas donde o Nilo / Nace [...] Vê-lo rega [...] Os povos Abassis, de Cristo amigos; / Olha como sem muros [...] se defendem [...] Vê Méroe, que ilha foi de antiga fama (X, 95, 1-7); Nesta remota terra [...] / Vê cá a costa do mar, onde te deu / Melinde hospício gasalhoso e caro (X, 96, 1 e 5-6); O Cabo vê já Arómata chamado (X, 97, 1); Vês o extremo Suez [...] / Olha as ágoas, nas quais abriu patente / Estrada o grão Mousés na antiga idade. / Ásia começa aqui [...] (X, 98, 1 e 5-7); Olha o monte Sinai, que se ennobrece / [...] Olha Toro e Gidá [...] / Olha as portas 
do Estreito [...] (X, 99, 1, 3 e 5); Olha as Arábias três [...] / Olha a costa que corre, até que cerra (X, 100,1 e 5); Olha Dófar [...] / Mas atenta: já cá destoutra banda / De Roçalgate (X, 101, 1 e 3-4); Olha o Cabo Asaboro [...] / Atenta a ilha Barém [...] (X, 102, 1 e 5); Olha da grande Pérsia o império nobre / [...] . Mas vê a ilha de Gerum [...] (X, 103, 1 e 5); Aqui de Dom Felipe de Meneses / Se mostrará a virtude $[\ldots](X, 104,1-2)$; Mas vês o fermoso Indo [...] (X, 105, 6); Vês, corre a costa célebre Indiana / [...] Por este mar a gente Lusitana [...] terá vitórias [...] (X, 107, 1, 5 e 7); Vê Catigão, cidade das milhores (X, 121, 5); Olha o reino Arracão; olha o assento / De Pegu [...] (X, 122, 1-2); Vês neste grão terreno os diferentes / Nomes de mil naçóes, nunca sabidas / [...] Vê nos remotos montes outras gentes (X, 126, 1-2 e 5); Vês, passa por Camboja Mecom rio $(\mathrm{X}, 127,1)$; Vês, corre a costa que Champá se chama / [...] Vês Cauchichina está de escura fama / [...] Aqui o soberbo império, que se afama (X, 129, 1, 3 e 5); Olha cá pelos mares do Oriente /As infinitas Ilhas espalhadas / Vê Tidor e Ternate [...] (X, 132, 1-3); Olha de Banda as Ilhas [...] Olha também Bornéu [...] (X, 133, 1 e 5); Ali também Timor, que o lenho manda / Sândalo, salutífero e cheiroso (X, 136, 1-2); Olha, em Ceiláo, que o monte se alevanta (X. 136, 1); Eis aqui as novas partes do Oriente (X,138, 1); etc. etc.

É tão insistente e iterativo o acumular de fórmulas deste tipo (bem perto de noventa) ao longo das cinquenta e uma estrofes (X, 91-141) dedicadas à descrição da geografia dos novos mundos, sobretudo orientais, que só o génio de um Camóes consegue evitar o risco da sua monotonia.

Mas, se é evidente a intenção e efeito visualista destes dois grandes discursos - o da apresentação das bandeiras da capitaina, e o da descrição da Máquina do Mundo -, efeito coadjuvado pela presença plástica de meios picturais no primeiro caso (os estandartes) e arquitectónicos no segundo (o globo cósmico), não é menos visualista um outro desenvolvimento descritivo d'Os Lusiadas, que ocupa quinze das primeiras vinte estrofes do Canto III, com a famosa e bela descrição da Europa, e que serve de introduçáo à maior analepse diegética de todo o poema, na qual o próprio Vasco da Gama conta ao rei de Melinde a história de Portugal e o seu enquadramento político-geográfico.

Também aqui, a linguagem usada pelo Almirante na apresentação da geografia geral do velho continente assume um acentuado carácter demonstrativo, marcado principalmente por vocábulos e expressóes indicativas de lugar, referentes ou próximas da $1^{\text {a }}$ pessoa, que transmitem ao ouvinte ou leitor a sensação de estar perante uma carta cosmográfica ${ }^{2}$.

${ }^{2} \mathrm{O}$ sentido visualista percorre outras partes da epopeia camoniana. Poderíamos quase dizer que $O s$ Lusíadas são um poema dominado pelo código da visualidade, que surge logo na dedicatória a D. Sebastiāo (I, 18, 5-8):

E vereis ir cortanto o salso argento

Os vossos Argonautas, por que vejam

Que são vistos de vós no mar irado. 
Depois de traçar os quatro limites cardeais da "soberba Europa", colocada entre a zona tórrida e a zona frígida do Norte, e limitada pelo rio Tánais e pelo mar Negro a oriente, pelo Oceano a poente e norte e pelo Mediterrâneo a sul, o narrador vai indicando e percorrendo as várias regióes, estados e povos, como se os apontasse a dedo sobre um verdadeiro mapa panorâmico do espaço europeu. Começando pelo canto superior direito desse mapa, é assim que ele assinala os lugares gelados que confinam com o Extremo Nordeste e as gentes que nele habitam:

Lá onde mais debaxo está do Pólo, Os Montes Hiperbóreos aparecem, $[\ldots]$

Por isso se compreende a frequência com que aparecem no poema, como já referimos, as formas dos verbos "olhar", "atentar", "enxergar" e outros, mas sobretudo "ver".

Quanto a este, as estatísticas mostram que, logo a seguir ao verbo "ser", com 697 ocorrências, é ele que ocupa o segundo lugar, com 444, muito antes de outros tão usados como "ter", "fazer", "estar", "ir", "vir", "poder", "haver" etc., que teoricamente pareceriam mais recorrentes (cf. Antônio Geraldo da Cunha, Indice Analítico do Vocabulário de "Os Lusíadas", Rio de Janeiro, Presença, 2a ediçâo, 1980, p. XVI).

Este recurso literário tem tradição antiga, e podemos encontar outros exemplos particularmente significativos na literatura portuguesa, anteriores e posteriores a'Os Lusíadas. Entre eles podemos citar v.g. a Miscelânea de Garcia de Resende (1554) e o Naufrágio de Sepúlveda de Jerónimo Corte Real (1594). Do primeiro, transcrevemos duas estrofes para verificação do uso do verbo "ver" (que neste poema aparece perto de 250 vezes). Seguimos a edição de Evelina Verdelho, Livro das Obras de Garcia de Resende, Edição crítica, estudo textológico e linguístico por [...], Lisboa, Fundaçâo Calouste Gulbenkian, 1994, pp. 570$571, n^{\circ} 181$, e p. $574, n^{\circ} 199$ :

\footnotetext{
Viimos riir, viimos folgar viimos cousas de plazer viimos zombar, apodar motejar, viimos trovar trovas que eram para leer; viimos homens estimados per manhas aventajados vimos damas muy fermosas muy discretas, e manhosas e galantes affamados.
}

\author{
Viimos moços governar \\ e velhos desgovernados \\ fracos, em armas falhar \\ e viimos muitos mandar \\ que deviam ser mandados; \\ viimos os bens estorvados \\ hos males acrescentados, \\ viimos clerigos viverem \\ com molher e hos filhos serem \\ dos beneficios herdados.
}

Quanto ao poema de Corte Real, o texto em causa é, curiosamente, também uma descrição da "Máquina do Mundo" dividida nas três clássicas partes de Europa, África e Ásia, que ocupa cerca de quinhentos decassílabos do Canto Segundo. Vd. Naufragio e Lastimoso Sucesso da Perdiçam de Manoel de Sousa de Sepulveda, \& Dona Lianor de Sá sua molher \& filhos [...], Composto em verso heroico, \& oitava rima por [...], in Obras de Jerónimo Corte Real [...] Introduçấo e revisão de M. Lopes de Almeida, Porto, Lello \& Irmão, 1979, p. 479 sqq., especialmente p. 532-547.

Sobre a questão do visualismo na épica camoniana, vd. António José Saraiva, "Os tempos verbais e a estrutura d'Os Lusíadas”, in Estudos sobre a Arte d'Os Lusíadas, Lisboa, Gradiva-Publicações Ldª 2a edição, 1995, pp. 7-28, Carlos Ascenso André, “A dimensão visual da épica camoniana”, IV Reunião Internacional de Camonistas, Actas, Ponta Delgada, 1984, p. 61-70 (e bibliografia aí citada na nota 1), e Fernando Gil e Helder Macedo, Viagens do Olhar, Retrospecção, Visão e Profecia no Renascimento Português (com uma contribuição de Luís de Sousa Rebelo), Porto, Campo das Letras, 1998, em especial o capítulo I. 
Aqui tão pouca força têm de Apolo

Os raios que no mundo resplandecem. (III, 8, 1-2 e 5-6)

Aqui dos Citas grande quantidade

Vivem, [...] (III, 9, 1-2)

Depois, bordejando o Norte e a caminho do Ocidente, indica as nações da Península da Escandinávia e outros países ribeirinhos do mar Báltico, bem como os povos de todo o Centro-Norte e Noroeste europeus até às fronteiras da França, sempre com expressóes demonstrativas ou indicativas de lugar:

Agora nestas partes se nomeia

A Lápia fria, a inculta Noruega,

Escandinávia Ilha, que se arreia

Das vitórias que Itália não lhe nega.

Aqui, enquanto as ágoas não refreia

$\mathrm{O}$ congelado Inverno, se navega

Um braço do Sarmático Oceano

Pelo Brússio, Suécio e frio Dano. (III, 10, 1-8)

Entre este mar e o Tánais, vive estranha

Gente: Rutenos, Moscos e Livónios. (III, 11, 1-2)

Retomando o Oriente, desce pelo Sudeste e percorre toda a restante faixa do Sul da Europa desde o mar Negro, passa pela Grécia, Dalmácia, Veneza e restante Itália e por toda a França até aos Pirenéus, sempre apoiado no mesmo processo de assinalar sobre o terreno várias gentes e terras, de tal modo que chega mesmo a incluir o vocativo animista de feição prosopopeica, aumentando assim a sugestão de uma realidade fisicamente visionada e da sua descrição presencial e, por assim dizer, teicoscópica, como se Vasco da Gama estivesse postado em um miradouro tendo diante de si uma visão panorâmica da Europa inteira ou, mais simplesmente, perante uma representação cartográfica:

Logo de Macedónia estão as gentes

A quem lava do Áxio a água fria;

E vós também, ó terras excelentes

Nos costumes, engenhos e ousadia,

Que criastes os peitos eloquentes

E os juízos de alta fantasia

Com quem tu, clara Grécia, o Céu penetras,

E não menos por armas que por letras. (III, 13, 1-8)

Logo os Dálmatas vivem; [...] (III, 14, 1)

Gália ali se verá, [...] /

Logo os montes da Ninfa sepultada /

Pirene se levantam, [...] (III, 16, 1 e 4-5) 
O texto culmina com a descrição particular da Espanha e de Portugal, colocados em posição de supremo destaque, como cabeça e topo da Europa inteira, nas famosas estâncias que Camóes lhes reserva, carregadas do mesmo sentido de espaço concreto e de evidência física:

Eis aqui se descobre a nobre Espanha,

Como cabeça ali de Europa toda. (III, 17, 1-2)

Com Tingitânia entesta, e ali parece

Que quer fechar o mar Mediterrano. (III, 18, 1-2)

Eis aqui, quasi cume da cabeça

De Europa toda, o Reino Lusitano

Onde a terra se acaba e o mar começa

E onde Febo repousa no Oceano.

Este quis o Céu justo que floreça

Nas armas contra o torpe Mauritano,

Deitando-o de si fora; e lá na ardente

África estar quieto o não consente. (III, 20, 1-8)

Esta é a ditosa pátria minha amada, /[...]

Acabe-se esta luz ali comigo.

Esta foi Lusitânia, derivada / [...] (III, 21, 1 e 4-5)

Desta o Pastor nasceu que no seu nome

Se vê que de homem forte os feitos teve. (III, 22, 1-2)

O efeito visual e o sentido de presencialidade narratológica que se desprende do conspecto descritivo desta Europa camoniana, em geral, e, em particular, a posição capitular que o Poeta atribui à Península Ibérica na configuração do panorama geográfico europeu; e, mais ainda, o lugar cimeiro e por assim dizer acmético reservado à Lusitânia (acentuado pelo carácter anafórico do demonstrativo "este", "esta") no desenho da mesma geografia, intrigam desde há muito os seus comentadores.

Alguns tentaram encontrar explicação para esta linguagem na influência de certa cartografia, designadamente dos mapas que representam a mesma Península com o Ocidente voltado para cima, isto é, com o rectângulo do território português à cabeça da própria Espanha, como acontece com o famoso mapa de Fernando Álvares Seco, de 1560/1561, o primeiro impresso que representou cartograficamente o espaço integral português $^{3}$ (vd. Mapa I):

3 Sobre este mapa, vd. Portugaliae Monumenta Cartographica, Vol. II, Estampas 197-198; e Alves Ferreira, Custódio de Morais, Joaquim da Silveira e Amorim Girão, "O mais antigo mapa de Portugal”, Boletim do Centro de Estudos Geográficos, Vol. II, no 12-13 (Coimbra, 1956), p. 1-66. 
MAPA I: Fernando Álvares Seco, 1560

(perspectiva: oriente $>$ ocidente)

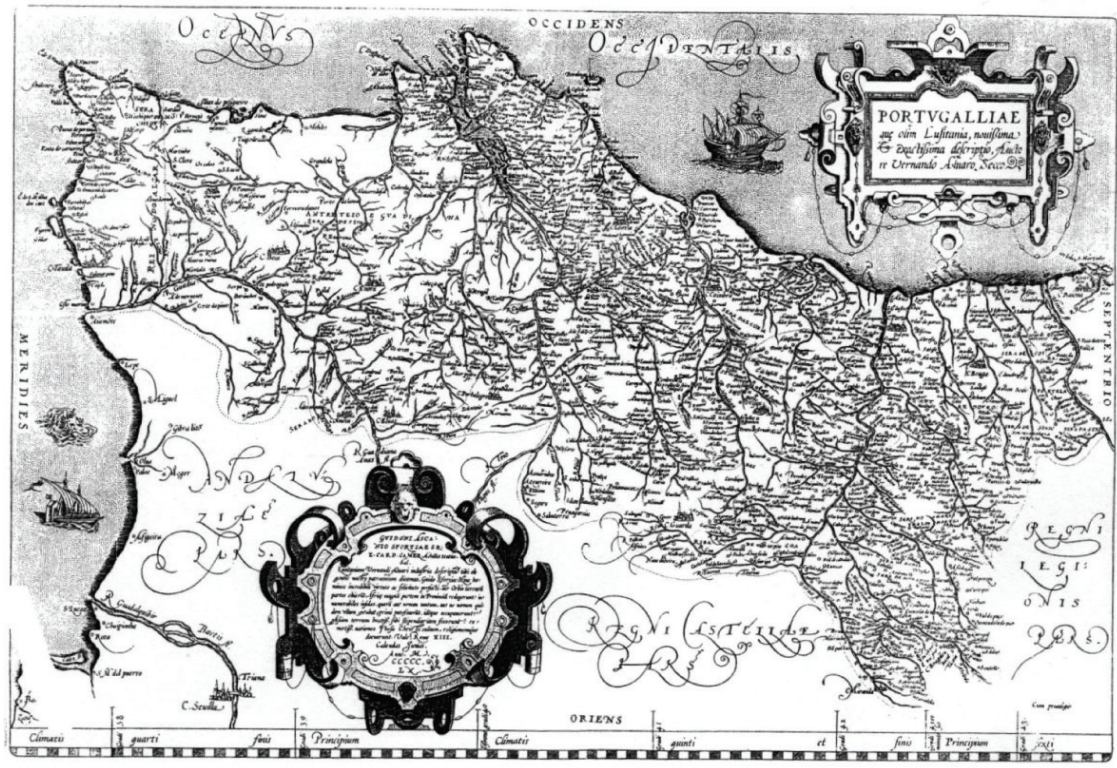

Fernando Álvares Seco, Portugalliae [...] Descriptio, Roma, 20 de Maio de 1560.

Quem, ao que parece, pela primeira vez chamou a atenção para a possível intertextualidade desta carta e da descrição camoniana dos dois países ibéricos foi Orlando Ribeiro, numa pequena nota crítica em que se refere à edição d'Os Lusíadas comentada por A. Epifânio da Silva Dias ${ }^{4}$. Com efeito, este comentador dá um sentido apenas metafórico ao texto camoniano que considera "a nobre Espanha, como cabeça ali de Europa toda" e Portugal "quasi cume" dessa cabeça, agarrando-se ao latinismo "quasi", isto é, "como se fosse", e louvando-se em dois testemunhos literários - Pedro de Medina 5

4 Vd. Orlando Ribeiro, "Notas e Recensões, Comentário geográfico a dois passos de Os Lusíadas", Finisterra: Revista Portuguesa de Geografia, Vol. VI, No 12 (Lisboa, 1971), p. 246-247. Cfr. Idem, "Camóes e a Geografia” in Estudos sobre Camóes, Páginas do Diário de Notícias dedicadas ao poeta no $4^{\circ}$ centenário da sua morte, Lisboa, INCM - Editorial Notícias, [1981], p. 35-36, e Opúsculos Geográficos: II Volume I Pensamento Geográfico, Lisboa, 1986, p. 26.

${ }^{5}$ Vd. Libro de las Grandezas y Cosas Memorables de España, Sevilha, 1548, cap. I (cf. Obras de Pedro de Medina. Edición y Prólogo de Ángel Gonçálvez Palencia, Madrid, Consejo Superior de Investigaciones Científicas, 1944, p. 7). Medina abre a sua obra com o capítulo intitulado "Cómo España es principio y cabeza de todas las regiones del mundo, de su assiento y figura”, fazendo notar que os antigos naturalistas e cosmógrafos, como Plínio e Ptolomeu, ao descreverem o mundo o dividiam em três partes - Europa, África e Ásia - e, por um lado, colocavam sempre o continente europeu em primeiro lugar dada a sua configuração geograficamente cimeira: "Y para decir destas comienza de Espańa así como principio y cabeza dellas". E, por outro, ao falar especificamente da Europa, é por sua vez a Espanha que, por análogo motivo, aparece à cabeça da sua descrição: "Tambén se muestra ser España principio, y cabeza de todas las otras regiones por demostración en su asiento y figura, porque si miramos las partes que dichas son [...] ninguna hay que 
e Frei Luís de Sousa ${ }^{6}$ - que usam o mesmo tipo de comparação. Ora, Orlando Ribeiro entendia que ao erudito "comentarista" Epifânio havia "escapado a explicação mais simples e clara", que era a de que "Camóes não emprega apenas uma metáfora mas uma imagem exacta: a nobre Espanha aparecia, de facto, como cabeça da Europa toda, e Portugal como ("quasi”) cume dela. Qualquer coisa que corresponderia, na figuração moderna da Europa, à Escandinávia e à Lapónia, como cume desta península. É evidente que o poeta utilizou ao máximo esta situação para, por meio dela, tirar efeito da preeminência que, de facto, a Espanha possuía na Europa do tempo".

A sensibilidade estética e a vasta e variada cultura do grande geógrafo Orlando Ribeiro, com a observação desta nota - que ele próprio se orgulhava de apresentar como uma novidade -, apontavam e abriam o caminho para um estudo intertextual que aproximasse a epopeia camoniana da história da geografia, como ele, aí mesmo, sugeria. Pena foi que náo tivesse aprofundado esta ideia e se quedasse pelo exemplo de um mapa, afinal, pouco convincente para o efeito. De facto, para o caso concreto da descrição camoniana da Península Ibérica, a carta de Álvares Seco, em que o resto da Europa está ausente e em que, da própria Espanha, pouco mais se vê do que um naco da raia com Portugal, a sua posição de "cabeça de Europa toda" só por longínqua dedução se pode imaginar.

Mas, levando esta pesquisa mais além, podemos encontrar documentos cartográficos muito mais sugestivos, como acontece com o Mappa Europae publicado pelo cosmógrafo Sebastião Münster em 1536, ou com a Moderna Europae Descriptio que ilustra várias das múltiplas ediçóes da Cosmographia Vniuersalis do mesmo autor, desde $1544 \mathrm{em}$ diante, os quais representam a visão de quase toda a Europa, desta feita com o sul voltado para cima, de modo que a Península Ibérica aparece posicionada à direita do leitor (de um leitor nórdico, evidentemente) e ligeiramente superior em relação ao resto do continente (vd. Mapa II) ${ }^{7}$.

tanto se muestre ser cabeza y principio de la universal redondez de la tierra como es la Espańa”. E, pouco depois, quando se refere aos Pirenéus, apresenta-os com uma das fronteiras naturais da Península Ibérica "por donde se ayunta y es tierra continente con la otra tierra de Europa: los cuales son así como cuello entre la cabeza, que es Espańa, y el cuerpo que son las otras partes del mundo”.

De resto, o título de "cabeça de Europa", atribuído à regiâo ibérica em geral, na sua expressão latina "caput Europae" pode ter sido sugerido por autores antigos como Dionísio Alexandrino, do séc. II d.C., que no seu De situ orbis afirma ter sido "a partir daí que a Europa primeiro ergueu a sua cabeça: "unde etiam Europa primum extulit caput" (cf. Opus de Situ Orbis [...], Venetiis per Franciscum Renner de Hailbrun .M.CCCC.LXXVIII., fol. B 7).

${ }^{6}$ Vd. História de S. Domingos, 1, 2, 1 (= ed. "Tesouros da Literatura e da História”, Porto, Lello \& Irmão - Editores, 1977, vol. I, p. 142-143). No capítulo I do Livro Segundo, em que trata "Do sitio da villa de Santarem: e do que nella se deu de novo ao Convento de S. Domingos de Montijrás”, Frei Luís de Sousa descreve a vila escalabitana servindo-se da configuração da mão do corpo humano: "huma mão esquerda apartada do braço, com a palma, e os dedos estendidos, e divididos hum do outro quanto naturalmente se podem alargar". Como o autor afirma, "Para dar a entender este sitio a quem o não viu" segue ["seguimos", diz ele] "o costume dos Geografos, que usão de comparação de alguns membros do corpo humano, pera se declararem na significação de outros do grande corpo da terra”.

7 Dentro da cartografia portuguesa, podemos lembrar, ainda, o "Mapa da Europa” de Lázaro Luís, de 1563, cuja leitura obriga a orientá-lo com o Ocidente para cima, tal como o de Fernando Álvares Seco, com a vantagem daquele, sobre este, de representar toda a Europa e não apenas Portugal (cfr. Portugaliae Monumenta Cartographica, Vol. II, estampa 223). 

MAPA II: Sebastião Münster, "Mapa da Europa”
(perspectiva: norte>sul).

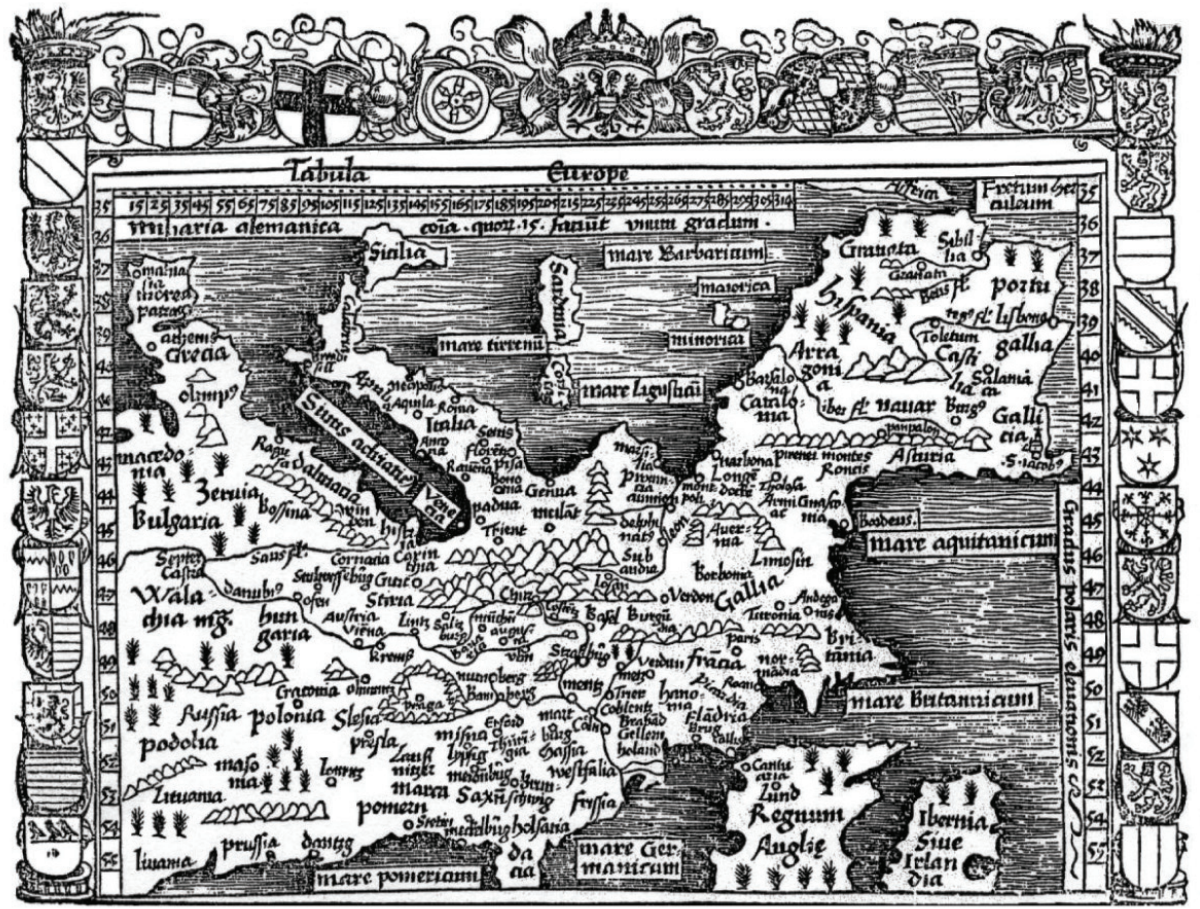

Sebastiāo Münster, Mappa Europae, Frankfurt am Main, 1536.

Tal circunstância favorece muito mais, como é evidente, a atribuição à Espanha e a Portugal da função de cabeça europeia; e a própria configuração do conjunto transmite, de algum modo, a sugestão de uma imagem antropomórfica, que tem por cabeça o território ibérico, por pescoço os Pirenéus, como tronco o Centro-Oeste, como braço direito a Itália e como esquerdo a Dinamarca, e ocupando o demais corpo a restante parte da Europa.

Foi, provavelmente, tal sugestão que levou alguns cartógrafos a conceder definitiva forma humana ao desenho geográfico do velho continente, representando-o sob a curiosa figura de uma jovem coroada como Rainha do Mundo e revestida com um manto tecido das naçóes de todo o espaço europeu, e que poderá esclarecer, como veremos, certas particularidades do texto camoniano na sua descrição da mesma Europa.

Entre as mais conhecidas figuraçóes deste tipo, que a seguir reproduzimos, contam-se: o mapa intitulado "Europa Prima Pars Terrae in Forma Virginis", publicado no Itinerarium Sacrae Scripturae de Heinrich Bünting, na cidade de Helmstadt em 15818; a carta da

${ }^{8}$ Este mapa tem vindo a ser reproduzido em Portugal por Rainer Daehnhardt, como ilustração da sua obra A Missão Templária nos Descobrimentos, Lisboa, Edições Nova Acrópole, 1991, p. 86, e em reedições posteriores. Cf. a edição de 1996, na mesma p. 86. 
"Europa Regina" ou "Descrição da Europa" do Manual Geográfico de Matias Quad, saída em Colónia em 1587; e principalmente aquela que ilustra a Cosmografia Universal de Sebastiâo Münster a partir da ediçáo póstuma de 1588 e que reaparece sucessivamente pelo menos até à edição de Basileia de $1628^{9}$ (vd. Mapas III, IV e V):

MAPA III: Heinrich Bünting, "Europa na figura de uma jovem” (perspectiva: sul>norte).

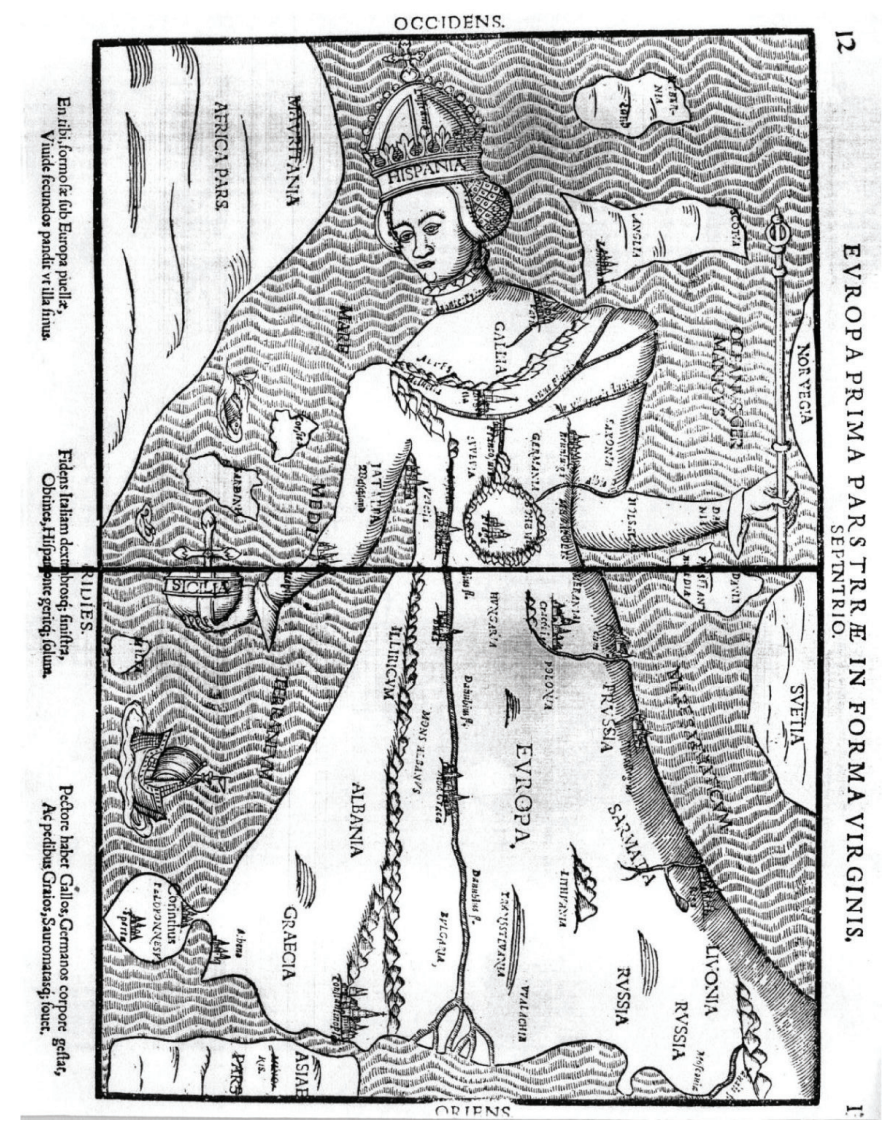

Heinrich Bünting, "Europa [...] in forma virginis", Itinerarium Sacrae Scripturae, Helmstadt, 1587.

9 Foi reproduzida designadamente nas ediçóes alemãs executadas pelo impressor Sebastian Heinrich Petri, naquela cidade, em 1592, 1598 e 1614. Trata-se de um dos mapas ginecomórficos da Europa mais conhecidos e que tem aparecido entre nós a ilustrar algumas publicaçóes, designadamente na História de Portugal (Direcção de José Matoso), Lisboa, Círculo de Leitores, Junho de 1993, vol. IV, p. 24; na revista Oceanos 16 (Lisboa, Dezembro de 1993), p. 13, à entrada do artigo de Martim de Albuquerque "Portugal e a consciência da "Europa"; na História de Portugal (Coord. de João Medina), vol. VI, p. 262-263; na Revista da Faculdade de Letras 18, 5a Série (Lisboa, 1995), p. 5-6, e na História de Portugal de António Leite da Costa, vol. I, Lisboa, Editorial Verbo, 2001, p. 11. 
MAPA IV: Matias Quad, "Europa rainha” (perspectiva: oriente $>$ ocidente).

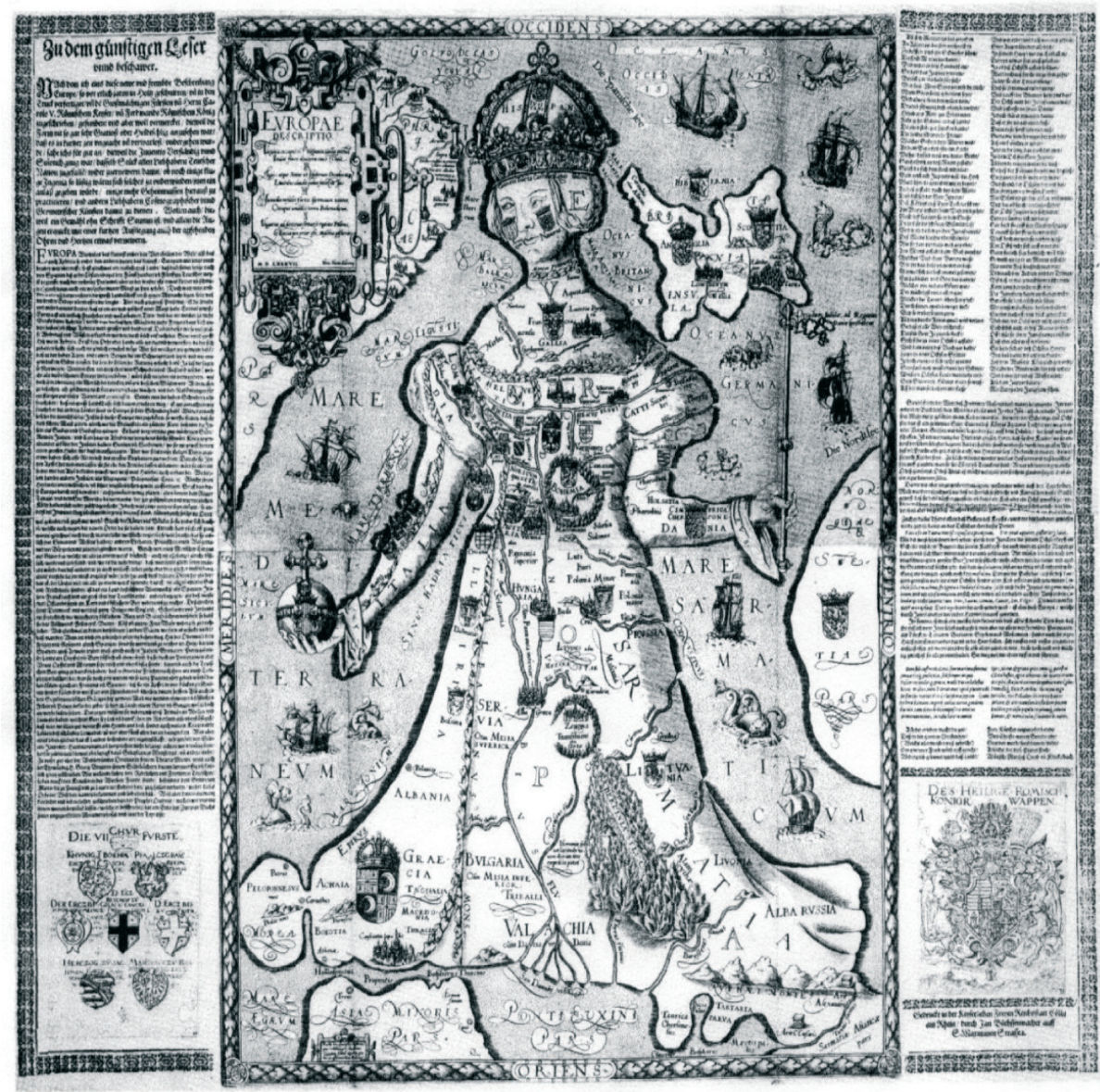

Matias Quad, “Europae Descriptio”, Geographisch Handtbuch, Colónia, 1587.

Este tipo de figuração ginecomórfica aplicado ao desenho topográfico da Europa assenta, como é evidente, no próprio mito da filha de Agenor raptada por Zeus disfarçado de touro de resplandecente brancura, e teve um enorme sucesso na representação do velho continente dentro da cosmografia mundial, em que a mesma imagem passou a ser largamente reproduzida com sucessivos aperfeiçoamentos ou adaptações. Um bom exemplo deste processo de transformação e do seu êxito são as diferentes versóes que foi apresentando o mapa da "Europa, primeira parte da Terra em figura de Jovem" (Europa Prima Pars Terrae In Forma Virginis) de Heinrich Büting nas reediçôes publicadas no seu Itinerarium Sacrae Scripturae, sucessivamente em 1595, 1610 e 1638, que aqui reproduzimos (vd. Mapas VI, VII e VIII): 


\section{MAPA V: Sebastião Münster, [Europa ginecomórfica}

(perspectiva: oriente>ocidente)].

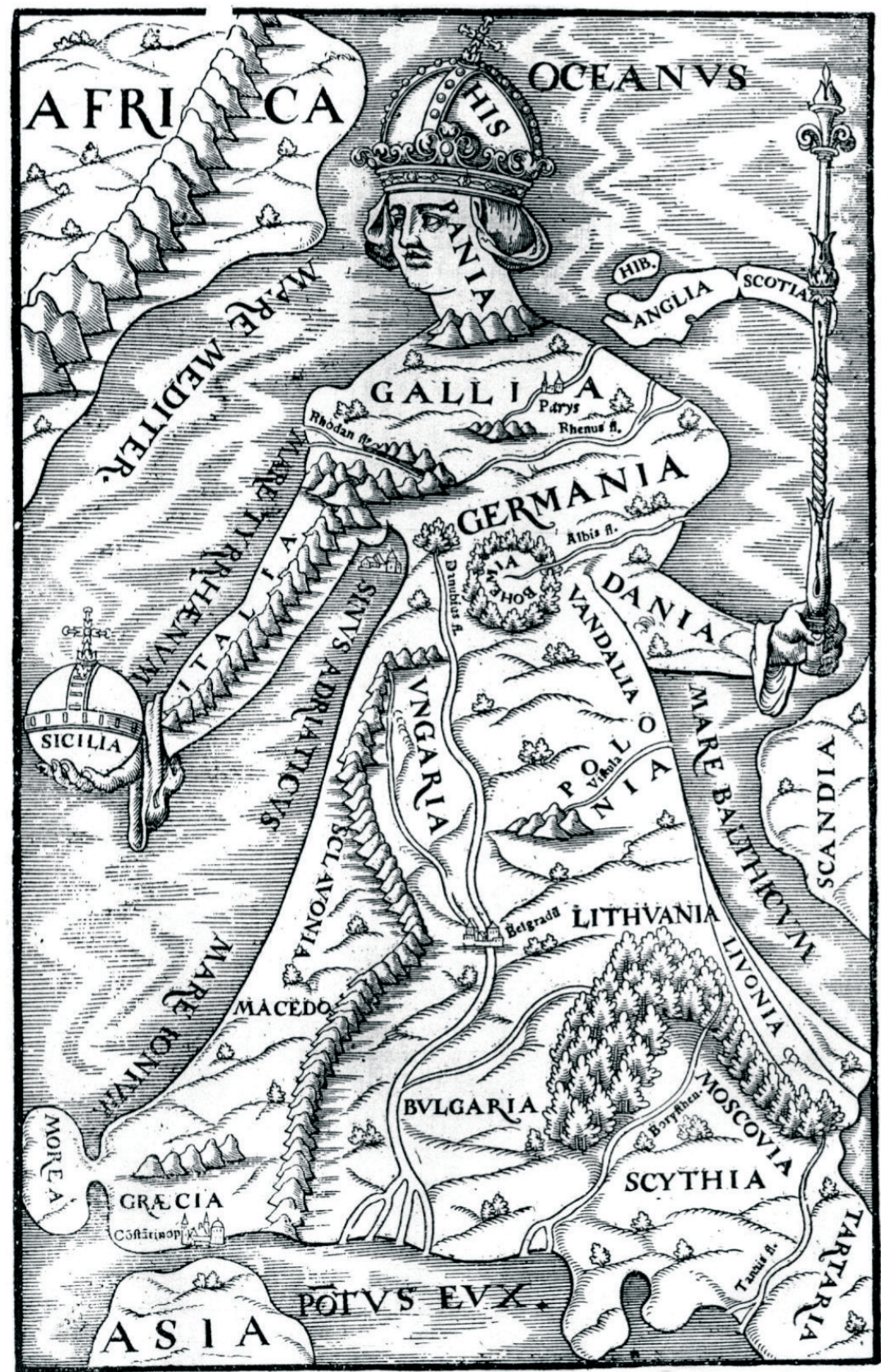

Sebastiāo Münster, "Europa”, Cosmographey [...], Basileia, 1588, fol.xlj. 
MAPA VI: Heinrich Bünting, "Europa na figura de uma jovem”

(perspectiva: sul $>$ norte).

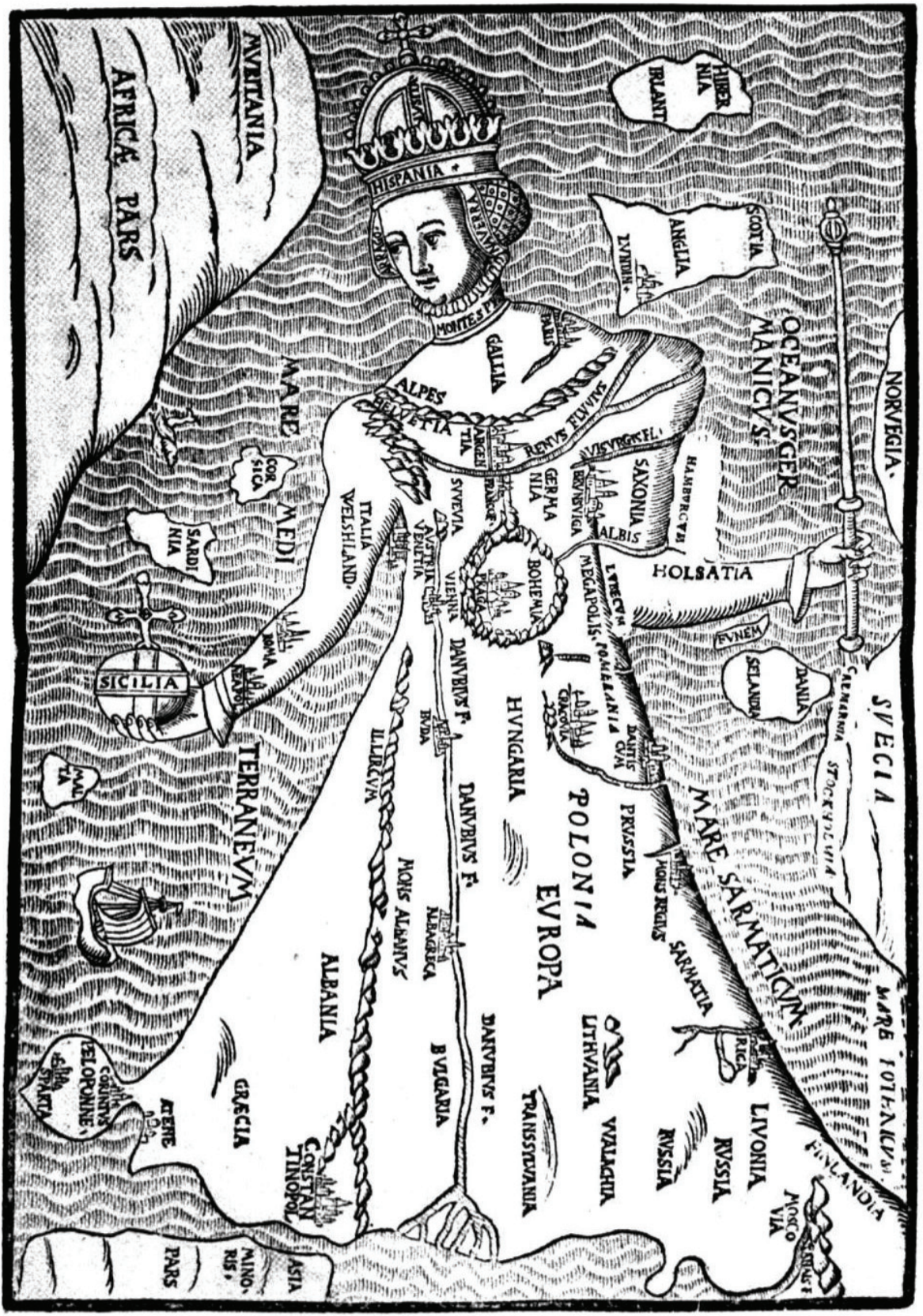

Heinrich Bünting, "Europa [...] in forma virginis",

Itinerarium Sacrae Scripturae, 1595. 


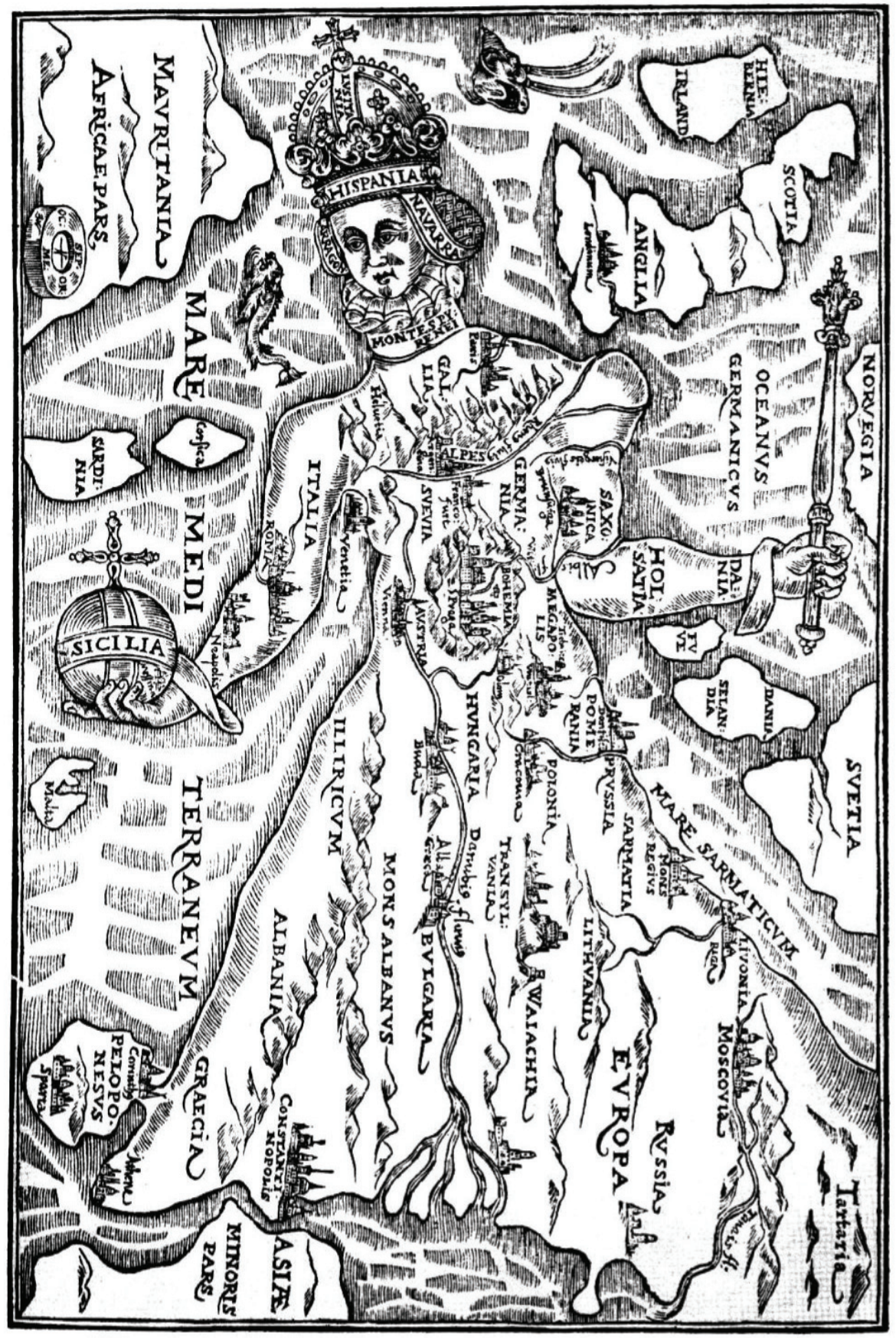

Heinrich Bünting, "Europa [...] in forma virginis",

Itinerarium Sacrae Scripturae, 1610. 


\section{MAPA VIII: Idem.}

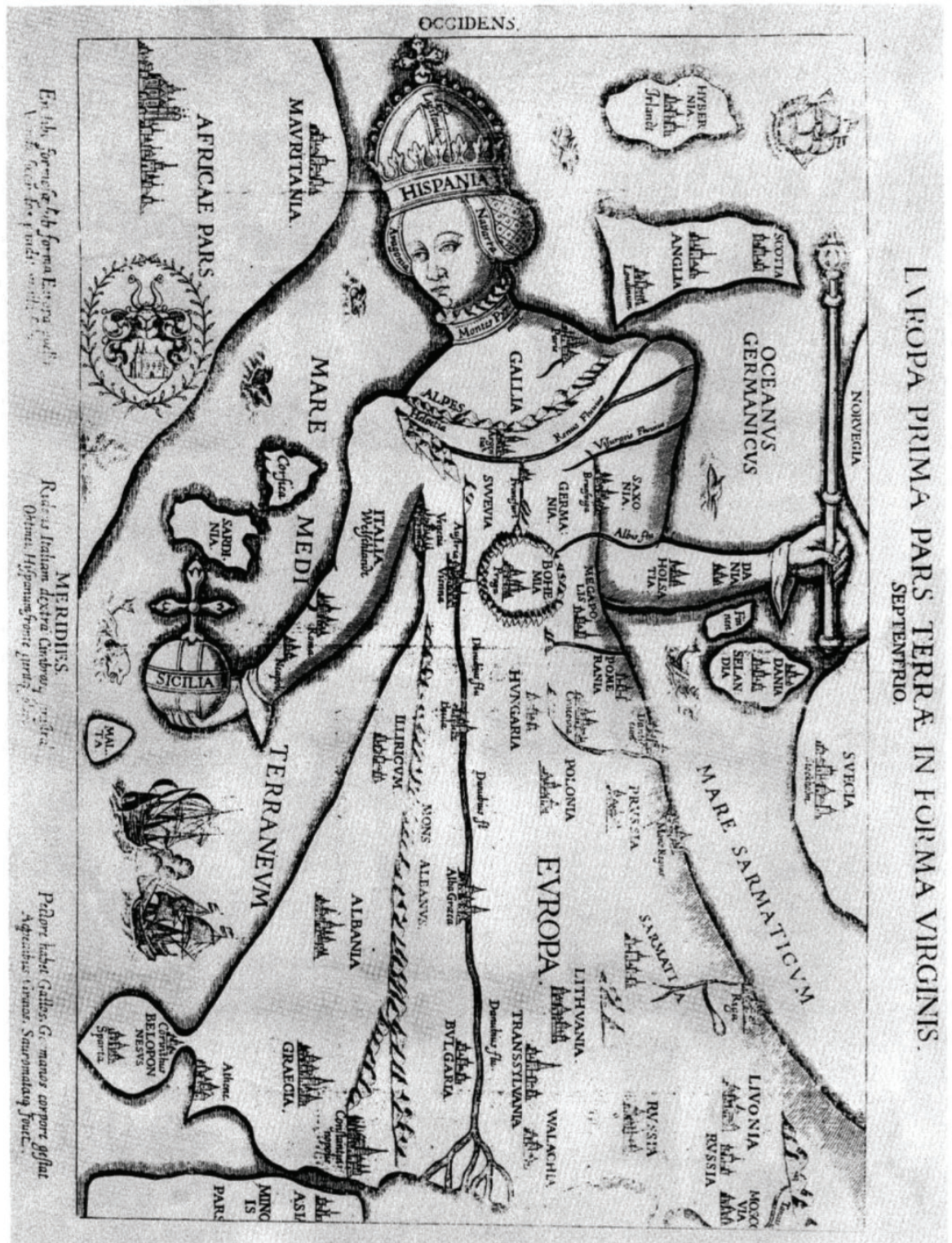

Heinrich Bünting, "Europa [...] in forma virginis",

Itinerarium Sacrae Scripturae, 1638.

Este recurso à cartografia figurativa, que assumiu também formas zoomórficas e fitomórficas, estendeu-se mesmo até aos nossos tempos e serviu diferentes finalidades, desde os propósitos literários da exaltação épica, ou da pedagogia e da simples decoração, 
até ao cómico e à sátira social e política, e não apenas da Europa, mas também de outros continentes. Ficaram famosas as figuraçôes da Ásia, sob a forma do Pégaso alado, e do conjunto dos três continentes, Europa, Ásia e África, representados no trevo de folha tripla, ambos do referido Heinrich Bünting (1581); o Leão Bélgico (Leo Belgicus) de Michel von Aitzing (1583, ou 1590?), a simbolizar os Países Baixos; as figuras do "Polvo" e da "Pesca em águas turvas" representativas da Rússia na Guerra da Crimeia (1877) e do Czar (1899), e publicadas por Frederick Rose, e muitos outros ${ }^{10}$. A mero título de exemplificação, reproduzimos aqui dois mapas de acerada sátira política, um de autor anónimo, publicado em 1598 por altura da revolta dos Países Baixos e sua libertação do domínio da Espanha, em figura feminina, claramente influenciado pela cartografia ginecomórfica anterior, e evocativo da derrota da Armada Invencível dez anos atrás; e outro, da autoria de H. Klokhoff, publicado em 1804 a simbolizar a divisão napoleónica da Europa, igualmente representada por uma mulher, que aqui ostenta a simbólica "Tesoura” por que ficou conhecido (vd. Mapas IX e X):

MAPA IX: Anónimo, [A Espanha, dez anos depois da Armada Invencível, na revolta dos Países Baixos], Amesterdão, 1598.

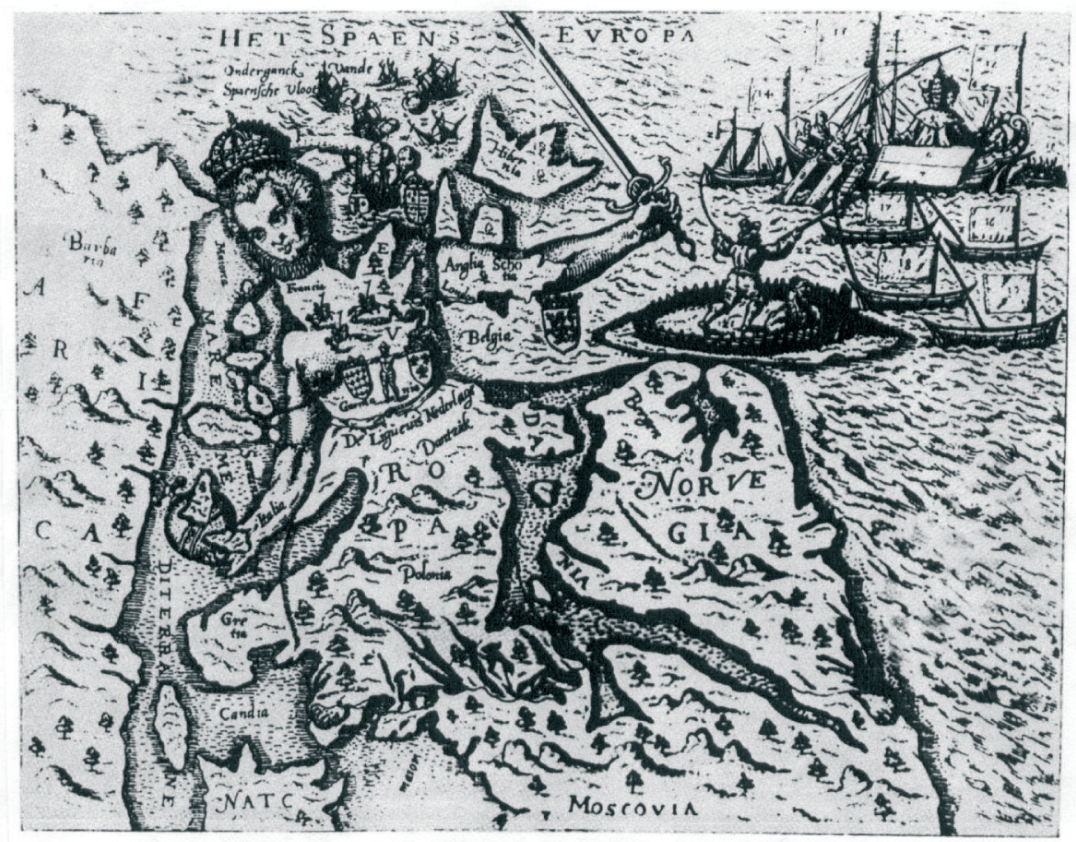

${ }^{10}$ Vd. Map Collector's Circle, Map Collectors'Series, no I: Geographical Oddities or Curious, ingenious, and imaginary maps and miscellaneous plats published in atleses. Described by R. V. Tooley and illustrated, Londres, 1963; Gillian Hill, Cartographical Curiosities, Londres, British Library, 1978; H. A. M. van der Heijden, De Oudste Gedrukte Kaarten van Europa, Canaletto, Alphen aan den Rijn, 1992. Agradeço ao meu colega António Manuel Ribeiro Rebelo o contacto com esta última obra, náo encontrada em bibliotecas portuguesas, e a prestimosa ajuda da sua leitura, e bem assim a indicação, a meu pedido, de outras fontes bibliográficas. 
MAPA X: H. Klokhoff, "A Tesoura",

[A divisão napoleónica da Europa], Haarlem, 1804.

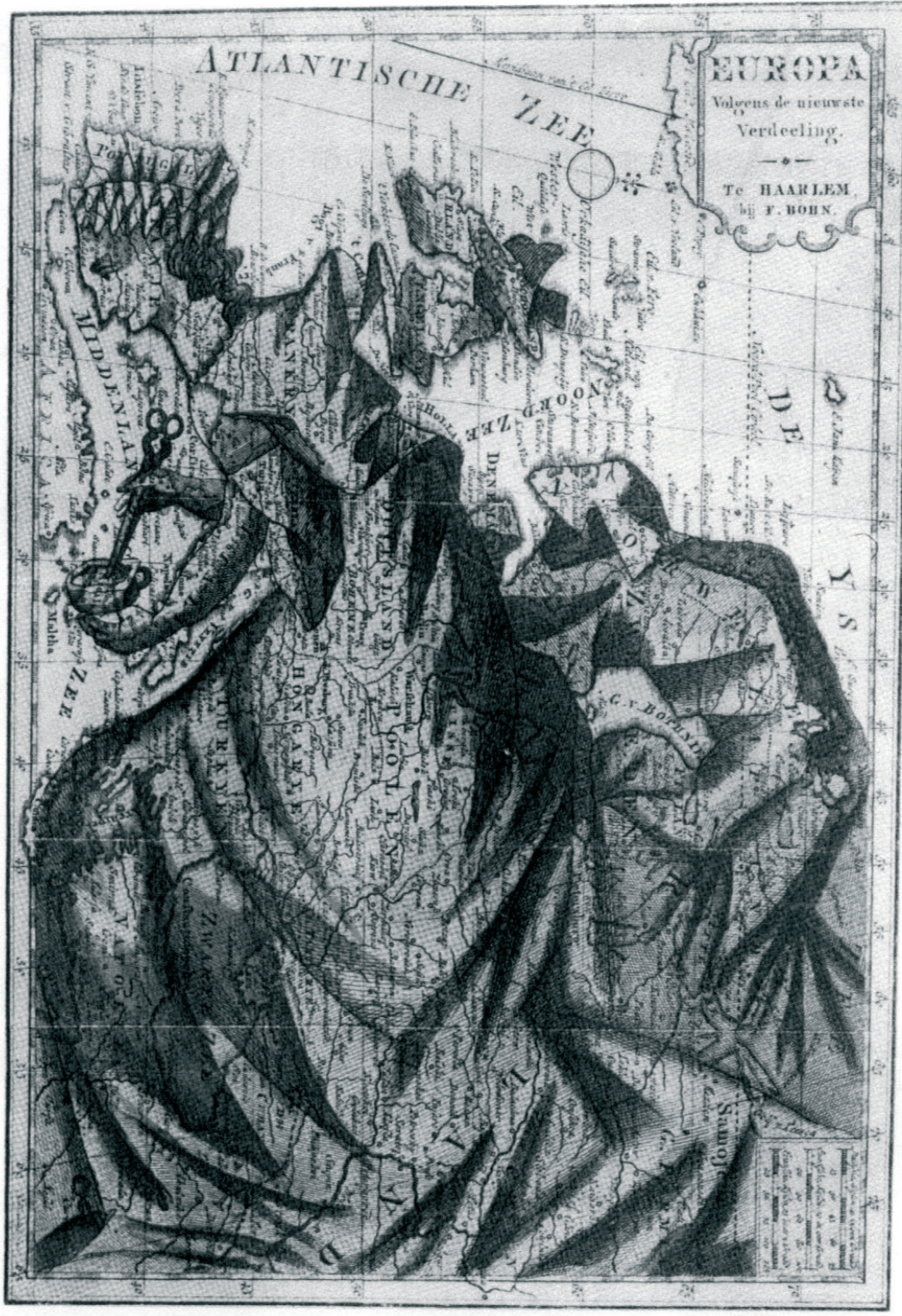

Mas, voltando às cartas do século XVI atrás referidas, e retomando a Europa ginecomórfica da Cosmografia de Sebastião Münster - a mais divulgada na época -, a sua configuração (vd., supra, p. 149, Mapa V), muito mais do que o já referido mapa de Portugal de Álvares Seco evocado por Orlando Ribeiro, facilmente recorda 
a qualquer camonista minimamente atento a descrição do continente europeu do Épico Português, particularmente no que respeita à Espanha como cabeça da Europa e a Portugal como se fora o seu vértice.

Devemos fazer justiça ao membro da Sociedade de Geografia de Lisboa, A. C. Borges de Figueiredo, que pela primeira vez, ao que sabemos, relacionou com um destes mapas, embora de passagem, aquela descrição camoniana da península hispânica, que, segundo palavras suas, lhe fazia lembrar "essa antiga carta onde a Europa é representada sob a forma d'um imperador (com a maior probabilidade Carlos V), cuja cabeça coroada fórma a Hispanha, o braço direito e o globo a Italia e a Sicilia, o braço esquerdo a Dinamarca, e uma bandeirinha do sceptro a Gran-Bretanha: compóe o resto da Europa o corpo coberto de veste ou manto" 11 .

É evidente que Borges de Figueiredo se referia concretamente ao mapa antropomórfico da Cosmografia Universal de Sebastião Münster, dada a referência à bandeirinha do ceptro ocupada pela Grã-Bretanha, quer dizer, pela Hibernia, Anglia e Scotia neste mapa, as quais, tanto nas versóes de Heinrich Bünting como de Matias Quad, aparecem independentes e até um tanto afastadas do mesmo ceptro.

A mesma sugestáo antropomórfica foi captada e magistralmente traduzida pelo poeta da Mensagem, cujo "Campo" introdutório descreve a Europa como uma mulher de cabelos românticos e olhos gregos, apoiando um dos cotovelos na Itália e o outro na Inglaterra e fitando o Ocidente com olhar esfíngico e um rosto que é Portugal ${ }^{12}$.

Recentemente, um outro grande poeta e camonista, Vasco Graça Moura, pressente e retoma a mesma aproximação figurativa em artigo publicado no número 16 da revista Oceanos, especialmente dedicado ao tema da Europa, chegando a afirmar que na descrição camoniana deste continente "se insinua também uma primeira noção de tipo antropomórfico, como que de corpo, que permitirá o encaixe natural das referências também geográficas do reino lusitano"13. A própria revista usa, para ilustração de um outro artigo do mesmo número 16, justamente a representação ginecomórfica da Europa publicada na Cosmografia de Sebastião Münster, como atrás referimos ${ }^{14}$.

Mais recentemente ainda, António Martins ilustra uma página da pequena História de Portugal de António Leite da Costa (que atrás citámos na nota 9), intitulada "A Cabeça da Europa", em que existe um manifesto relacionamento entre o mapa antropomórfico europeu de Münster e a Península Ibérica, não tanto no texto do livro, como sobretudo na legenda do mesmo mapa, embora com erros cronológicos que impossibilitam a sua influência em Camóes, como vamos ver.

${ }^{11}$ Vd. A. C. Borges de Figueiredo, A Geografia dos Lusiadas de Luis de Camóes, por [...], Lisboa, Typographia de Adolpho, Modesto \& Ca., 1883, p. 22.

12 Vd. Fernando Pessoa, "Mensagem”, Obra Poética, I Volume, Lisboa, Círculo de Leitores, 1987, p. 111, vv. 1-12.

13 Vd. Vasco Graça Moura, “Camôes e uma concepção da Europa”, Oceanos 16 (Dezembro de 1993), p. 59, col. 2 .

${ }^{14} \mathrm{Vd}$. supra, na nota 9, a referência ao artigo de Martim de Albuquerque. 
A cartografia antropomórfica até aqui evocada apresenta, porém, uma questão cronológica na sua relação com o texto camoniano, pois todos os respectivos mapas pertencem a ediçóes posteriores à publicação d'Os Lusiadas, o que obviamente torna impossível o seu conhecimento por parte do Poeta. Compreende-se, pois, que, apesar das diferentes aproximações feitas por vários investigadores já aqui mencionados, ninguém até hoje, que saibamos, tenha procurado relacionar estes mapas com a descrição camoniana da Europa no sentido de provar ou sequer tornar possível a hipótese de ver neles uma fonte em que o Épico Português pudesse encontrar o apoio icónico explícito, fisicamente presente ou reservado no seu imaginário cultural, que falta naquela descrição. Para admitir o eventual contacto de Camóes com representaçóes ginecomórficas deste tipo, importaria descobrir a existência de fontes anteriores a 1572. Foi o que procurámos saber ${ }^{15}$.

Com efeito, sabemos agora que, em primeiro lugar, a cartografia figurativa e designadamente a representação antropomórfica da Europa têm uma tradição que remonta à Idade Média, como podemos verificar em desenhos manuscritos, por exemplo, de Opicinus de Canistris, concebidos para ilustrar um texto, redigido entre 1334 e 1342, destinado à corte pontifícia por altura do exílio dos Papas em Avinhão. Um desses desenhos mostra a Europa sob a forma de uma jovem, a simbolizar a Igreja Católica libertada do seu sedutor, que ocupa o Norte de África, provavelmente a alegoria do cisma religioso do Ocidente, segundo pudemos deduzir das legendas latinas acumuladas à volta da figura (vd. Mapa XI) ${ }^{16}$.

Em segundo lugar, ficamos também a saber que todas as referidas cartas de Bünting, Matias Quad, Münster e de outros cosmógrafos, publicadas a partir de 1587, são imitaçóes que assentam num mapa original desenhado pelo austríaco Johann Putsch em 1537 e gravado numa nova versão em 1548, o qual, por essa época, corria impresso em folhas volantes que Camóes poderia ter conhecido, embora hoje constituam verdadeiras raridades museológicas.

Trata-se de um mapa da Europa in forma virginis coroada, que Putsch dedicou a Fernando I da Casa dos Habsburgos, rei da Hungria, da Boémia (1526) e dos Romanos (1531), arquiduque de Áustria e futuro sucessor de seu irmão Carlos V, cujos títulos o autor lhe consagrou na seguinte dedicatória latina exarada no canto superior esquerdo,

\footnotetext{
15 Quando este artigo já estava pronto a sair na Revista Camoniana tive conhecimento, por amável informação da minha colega Rita Marnoto (a quem penhoradamente aqui agradeço), do artigo de Arlindo José Nicau Castanho, "Camöes, Pessoa e le carte simboliche del'<Europa fanciulla>", publicado em $L a$ Cultura nel Mondo (Direttore: Leo Magnino), Anno L, numero unico, Roma, 1996, pp. 27-34. O autor coloca (e muito bem) a questão de Camôes se ter servido de mapas deste tipo, mas parte de informaçóes erradas, designadamente de que o mapa da "Europa fanciulla” fora publicado por Sebastiẫo Münster desde a ediçấo de 1544 da sua Cosmographia Vniuersalis, quando se sabe que esta passou a ser ilustrada por essa carta ginecomórfica apenas a partir da edição póstuma de Genebra de 1588. Mas, apesar de a questão não ter ficado, por isso, documentalmente resolvida por Arlindo Castanho, verificamos com satisfaçáo que o autor faz uma análise de aproximação de alguns dados destes mapas com o texto camoniano que coincide com muitos dos nossos pontos de vista e com as nossas conclusôes.

16 Vd. Códice Vaticano Latino 6435, fol. 84v. Cf. John Goss, Kartenkunst. Die Geschichte der Kartographie, Braunschweig, 1994 (trad. alemã do original inglês The Mapmaker's Art. A History of Cartography), p. 330; e Leo Bagrow, Die Geschichte der Kartographie, Safari-Verlag-Berlin, 1951, p. 20.
} 
MAPA XI: Opicinus de Canistris,

"A Igreja, liberta do sedutor", 1334-1338.

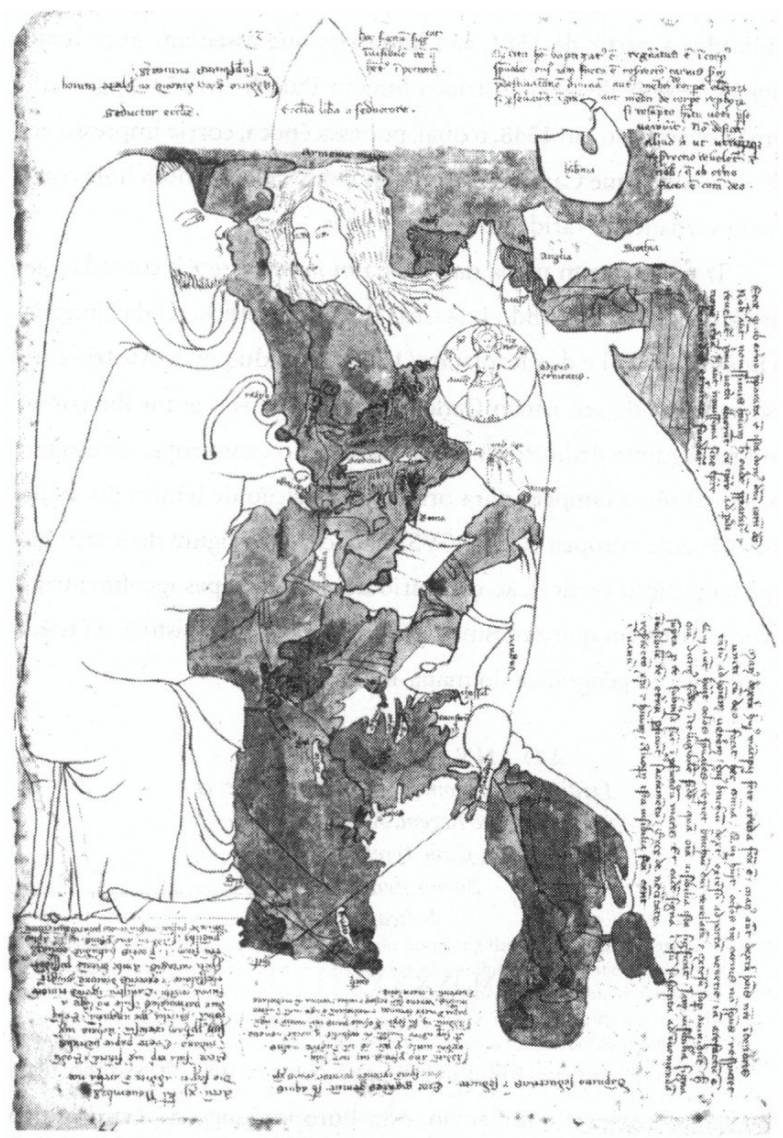

Opicinus de Canistris, "Ecclesia libera a seductore", Ms. Vat. Lat. 6435, fol. $84 \mathrm{v}$.

a qual serve também para orientar a posição de leitura do mapa, com o Poente europeu (OCCASVS) para cima e a figura da jovem Europa na posição vertical, ao contrário de outros mapas igualmente ginecomórficos em que a mesma figura aparece deitada, isto é, na tradicional posição geográfica do mapa-múndi:

A D I N V I C T I S S I M V M

Ferdinandum Romanorum, Hungariae, et

Bohaemiae Regem, Archiducem Au-

striae, Cum Tyrolis Ioannes

Bucius Aenicola

dedicat.

M. D. X X X V I I. 
Trata-se de uma folha avulsa que ostenta no seu reverso uma tábua que descreve, em alemão, esta Europa figurada, e cujo único exemplar conhecido pertence ao Tirol Landesmuseum Ferdinandeum, de Insbruk. É dele a reprodução que a seguir apresentamos (vd. Mapas XII e XIII) ${ }^{17}$ :

MAPA XII: Johann Putsch, [Europa ginecomórfica], 1357.

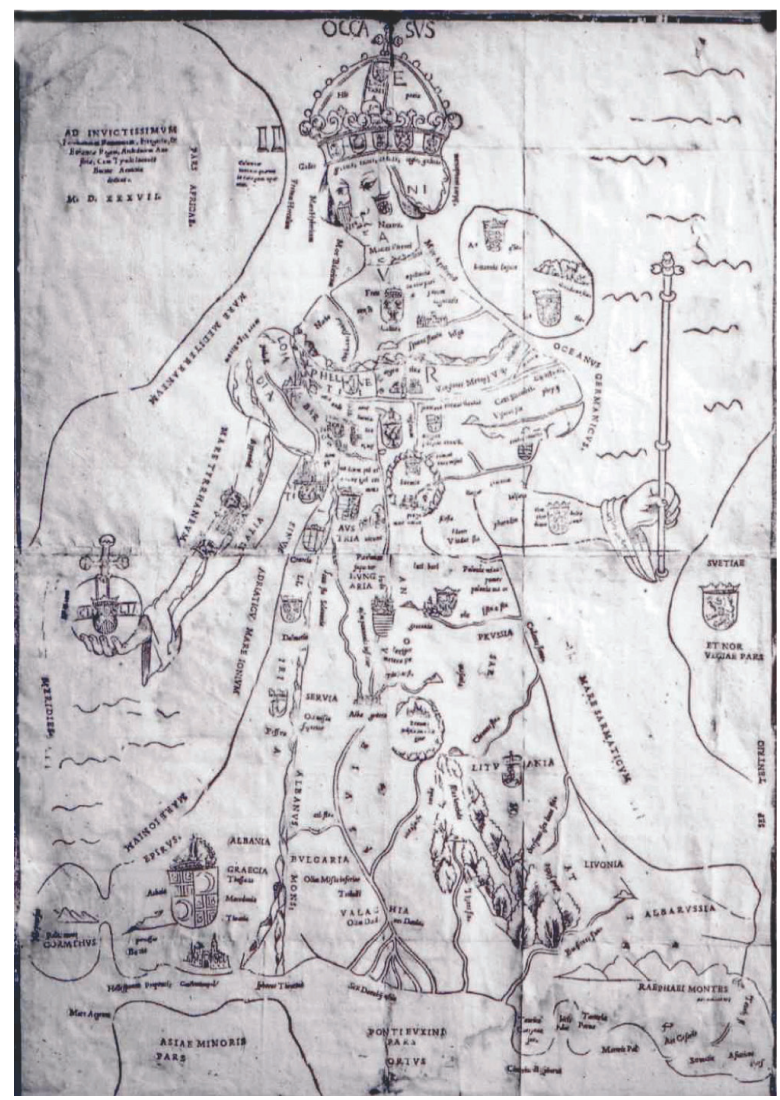

A mais antiga versão conhecida da representação da "Europa-Virgo" de Johann Putsh (1537).

${ }^{17}$ Agradeço à Dra Sieglinde Sepp, Directora do Abteilung für Sondersammlungen da Biblioteca da Universidade de Insbruck, a pronta e eficiente disponibilidade para me providenciar a cópia desse mapa e demais documentação biobibliográfica sobre o seu autor, existentes no referido Museu, bem como devo e agradeço à minha colega Maria Manuela Delille a amabilidade de me ter facilitado os contactos com a referida Directora. Este mapa foi publicado pela primeira vez em obra moderna, ao que sabemos, por $\mathrm{H}$. A. M. van der Heijden, De Oudste Gedrukte Kaarten van Europa, Canaletto, Alphen aan den Rijn, 1992, p. 121, carta no 41 . O autor faz aí (pp. 118 sq.) um minucioso estudo em que descreve a origem deste mapa e o seu uso posterior na ilustração de obras de cosmografia, com sucessivas adaptaçóes, designadamente na Cosmografia de Sebastiâo Münster a partir de 1588. 
MAPA XIII (=Reverso do mapa XII) ${ }^{18}$.

14 Rurize Erflerung Diefer Inffeli.

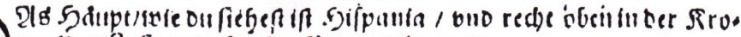

netl liege Eufitanin/foupien portugnl genent.

Das rectec D br if Errogonia/vilo anffocm linfen Dhr/bue man bas Ranigreles Ylubarra.

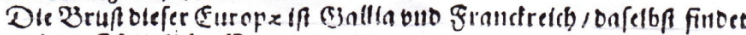

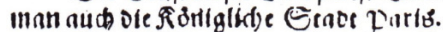

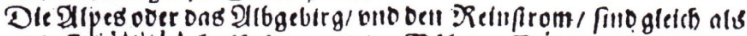

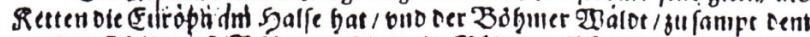

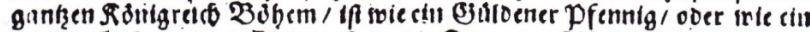

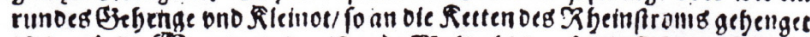

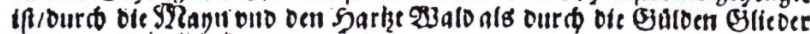
Eetoene Ëकniurieln.

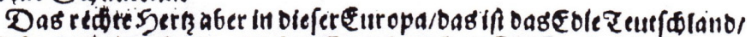

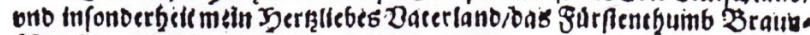
fợelá.

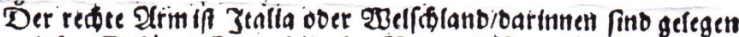

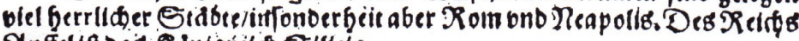
Ipffelift oas. Rdnigrétis Siltia.

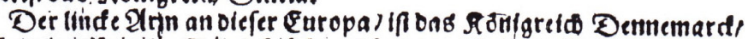

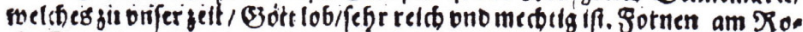

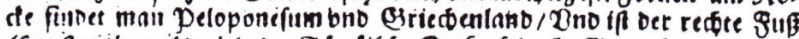

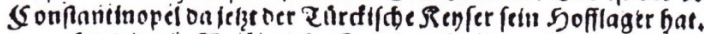

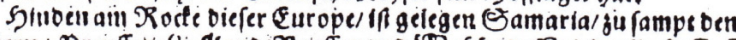

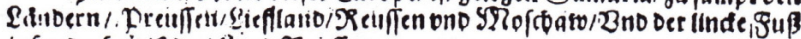
infouderbeit ifi Das Lano Reinfen.

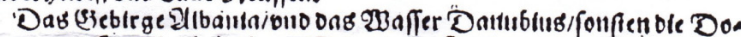

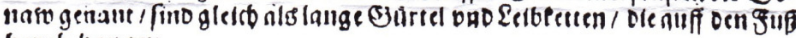
berab bongeil.

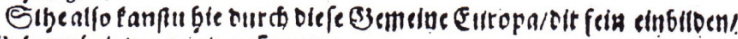
cie Bjelegentieft ber ganlzeti curopx.

${ }^{18}$ Apresento aqui a tradução desta tábua, feita pelo meu colega Ludwig Franz Scheidl, a quem agradeço penhoradamente:

"Breve Explicação destas Tábuas

Como vês, a cabeça é a Espanha, e à direita em cima na coroa fica a Lusitânia, também chamada Portugal.

A orelha direita é Aragão, e na orelha esquerda está o Reino de Navarra.

O peito desta Europa é a Gália e a França, aqui se encontra a cidade real de Paris.

Os Alpes, ou Cordilheira Alpina, e o rio Reno são como que fios que a Europa tem à volta do pescoço, e a Floresta da Boémia, juntamente com todo o Reino da Boémia, é uma moeda de ouro, ou como um pendente redondo e jóia, como que presos ao fio do rio Reno, através do rio Meno e da Floresta do Hartz como elos de ouro entrançados num fio de seda.

Mas o verdadeiro coração nesta Europa é a nobre Alemanha, e em especial a minha amada pátria, o Principado de Braunschweig.

O braço direito é a Itália, lá se encontram muitas cidades magníficas, em especial Roma e Nápoles. A maçã do reino é o Reino da Sicília.

O braço esquerdo desta Europa é o Reino da Dinamarca, o qual no nosso tempo é, graças a Deus, muito rico e poderoso. À frente na veste encontra-se o Peloponeso e a Grécia, e o pé direito é Constantinopla, onde agora o Imperador turco tem a sua corte.

Atrás, na veste desta Europa, fica a Sarmácia juntamente com os países da Prússia, de Liefland, da Rússia e de Moscovo, e o pé esquerdo é em especial o território da Rússia.

A Albânia montanhosa e a corrente Danubius, conhecida por Danúbio, são como que o cinto comprido e as correntes que pendem até ao pé.

Vê, pois, se és capaz de imaginar, através desta Europa comum, a disposição de toda a Europa.” 
Esta versão original, publicada em Paris por Christian Wechel em $1537^{19}$, apresenta um traço de certo modo mais simples do que a maior parte das suas sucessivas imitaçóes tardias, mas em contrapartida fornece informaçóes por vezes mais abundantes que confirmam e iluminam muito do antigo vocabulário etnográfico e toponímico usado por Camóes na sua descrição da Europa, designadamente a menção de Citas, Moscos, Livónios, Sármatas, Polónios, Sáxones, Boémios, Traces e Dálmatas, do Dano e do Brússio, e os nomes dos rios Tánais, Séquana e Álbis, dos montes Rifeus, da floresta ou montanha Hircínia, da "alagoa" Meótis (a Maeotis palus, equivalente ao moderno mar de Azof), do Sarmático Oceano, entre outros.

Além disso, ajuda a esclarecer algumas das designaçóes camonianas da geografia física, como a de que a Escandinávia era uma ilha (a "Escandinávia Ilha", de Lus., III, 10, 3), porquanto a sua configuraçáo nestas cartas mostra apenas uma ou duas partes deste território separadas do resto do continente, embora se saiba que o poeta terá recebido esta expressão também de fontes bibliográficas, como as Enneades de Sabélico ${ }^{20}$. Os historiadores Jean Carpentier e François Lebrun, na sua História da Europa, chamam a atenção para este erro da geografia, ainda vigente no séc. XVI como o demonstram, segundo eles, justamente alguns destes mapas ginecomórficos da Europa ${ }^{21}$.

Mas é sobretudo a própria linguagem antropomórfica do texto camoniano que pode reflectir influências do desenho, do conteúdo e da disposição destes mapas quinhentistas.

19 Poucos anos depois, Guillaume de Postel, ao falar da "Hispania" e da sua configuração física e ao lembrar várias comparaçôes da tradição feitas a seu respeito, na sua Cosmographiae disciplinae Compendium [...], Basileae, per Ioannem Oporinum, 1561, fol. 5, escreve as seguintes palavras: "Christianus Vuechelus aliquando, nescio quo authore, Iapetiae formam typis ita expresserat, in gratiam Caroli V Imp. ut esset instar feminae capite inclinato, diadema Imperatorium gestantis, ita ut caput Hispania, sinister humerus Gallia, pectus Germania, sinistra manus Danemarkia, dextrum brachium Italia, cetera quae Turcis aut Moscouitis subsunt, ad infimos pedes suis longis uestibus obtectos pertinerent; non omnino inepta (modo adulationem tollas) inuentione", isto é, "Christian Wechel publicara em tempos, em agradecimento ao Imperador Carlos V, uma gravura da Japécia, não sei de que autor, de tal maneira desenhada que parecia uma mulher trazendo um diadema de imperador sobre a cabeça inclinada, e de tal modo que a cabeça é a Hispânia, o ombro esquerdo a França, o peito a Alemanha, a mão esquerda a Dinamarca, o braço direito a Itália, e tudo o resto, que está sujeito a Turcos e Moscovitas, estende-se até à ponta dos pés recobertos por seus longos vestidos, num achado de modo algum desajustado, adulaçáo à parte”. Note-se que o nome de Japécia (ou Jafécia) dado à Europa traduz a teoria e tradição de raiz bíblica que toma como epónimo deste continente, não Europa filha de Agenor, mas Japhet filho de Noé, que lhe teria confiado o espaço europeu, ocupado pelos seus descendentes, entre os quais figura Thubal, a quem coube a Hispânia. Esta referência de Postel, feita em 1561, a um tal mapa, embora para ele desconhecido, prova que não se trata das versóes preponderantes publicadas mais tarde por Sebastiāo Münster e outros (vd. Mapas III, IV e V), mas do próprio desenho de Johann Putsch de 1537, ou de uma cópia deste feita por um gravador CP, de que há notícia (vd. Map Collector's Circle cit., p. 3 e p. 7 no 6), ou ainda de qualquer reedição destes anterior àquela data.

${ }^{20}$ Vd. José Maria Rodrigues, Fontes dos Lusíadas, Lisboa, 21979 , p. 220-221.

${ }^{21}$ Vd. Jean Carpentier e François Lebrun, História da Europa (Trad. de Manuel Ruas), Lisboa, Editorial Estampa, 1993, p. 29: "Em meados do século II depois de Cristo, Ptolomeu continuava a julgar que a Escandinávia era uma ilha do Oceano Sarmático. E assim foi durante séculos, como prova aquela alegoria do século XVI que nos mostra a Europa na figura de uma Virgem coroada que tem por cabeça a Espanha, por coração a França, por ventre a Germânia e por braços a Itália e a Inglaterra mas cujo vasto manto, de dobras incertas, é o confuso horizonte das planuras russas". 
Assim, uma dessas formas linguísticas de carácter antropomórfico tem que ver com a referência à Itália. Quando Camôes descreve o Sul da Europa em direcção ao Ocidente, entra na Península dos Apeninos com estas palavras da estância 14 do canto III:

Da terra, um braço vem ao mar, que, cheio

De esforço, nações várias sojeitou;

Braço forte, de gente sublimada,

Não menos nos engenhos que na espada. (III, 14, 1-8)

Não deixa de ser estranha esta designação de "braço" aplicada a um prolongamento de terra pelo mar adentro, justamente ao contrário do seu sentido habitual, isto é, o de uma passagem ou entrada de água pelo interior da terra, por exemplo um braço de mar ou mesmo de um rio. Com efeito, tratando-se, afinal, de um promontório, seria normal esperar que o poeta usasse o termo corrente "cabo", que por sinal tem a mesma estrutura métrica e prosódica e, por isso, cabe rigorosamente na medida e no ritmo interno do verso; e tanto mais que é palavra recorrente n'Os Lusíadas com sentido hidrográfico ${ }^{22}$. A confirmar o carácter excepcional deste passo está o facto de que, dos cinco casos em que Camóes usa o vocábulo "braço" com esse mesmo valor, só aqui ele assume aqueloutro sentido oposto ${ }^{23}$. Fica, porém, desfeito o enigma se o entendermos no contexto da configuração antropomórfica dos aludidos mapas cartográficos, em que a Itália ocupa justamente o verdadeiro braço direito da figura da "Europa Regina".

Do mesmo modo, quando Camóes descreve a posição da Espanha frente ao Norte de África - a sua Tingitânia - e ao estreito de Gibraltar, que as separa, usa duas formas verbais de cariz acentuadamente antropológico:

Com Tingitânia entesta, e ali parece

Que quer fechar o mar Mediterrano,

Onde o sabido estreito se ennobrece

Co extremo trabalho do Tebano. (III, 18, 1-4)

O verbo "entestar", que, de resto, aparece esta única vez em todo o poema - um verdadeiro hápax d'Os Lusiadas -, quadra perfeitamente com a posição da cabeça humana de cada um dos mapas aqui aduzidos e traduz da maneira mais feliz a postura e o aspecto da figura feminina que representa a Europa de fronte iminente e voltada para a África. Aliás, o sentido fisionómico daquele verbo é confirmado por toda a outra frase que vem logo a seguir - "e ali parece / Que quer fechar o mar Mediterrano" -, centrada no verbo "querer", que concede à descrição um carácter de manifesto animismo.

${ }^{22} \mathrm{Vd}$. Os Lusíadas, V, 7.

${ }^{23} \mathrm{Vd}$. os outros quatro passos d'Os Lusíadas, a saber: I, 91, 7: o "estreito braço" de mar que separa a ilha de Moçambique da costa; III, 10, 7: o "braço do Sarmático Oceano", isto é, do mar Báltico; VII, 19, 5-6: "o largo braço / Gangético" ou seja, o rio Ganges; e X, 13, 4: "nos braços do salgado e curvo rio", isto é, do rio de Cochim. 
Finalmente, importa apreciar os dois passos camonianos em que as duas naçôes da Península Ibérica assumem o protagonismo da descrição camoniana da Europa geográfica, e verificar como essa preeminência se revê nos mapas ginecomórficos do velho continente:

Eis aqui se descobre a nobre Espanha,

Como cabeça ali de Europa toda. (III, 17, 1-2)

\section{Eis aqui, quasi cume da cabeça \\ De Europa toda, o Reino Lusitano. (III, 20, 1-2)}

A designação da Espanha como "cabeça" da Europa, quando confrontada com a figuração da jovem coroada - e não de Carlos V, como se pensou ${ }^{24}$ - destes mapas ginecomórficos, não tem nada de metafórico, pois o desenho da cabeça da jovem corresponde justamente ao espaço ibérico da descrição de Camóes, que aí vem identificado com o nome de Hispania, embora o Poeta a utilize para traduzir, no plano épico, o papel de capital importância política que ela então exercia no concerto das naçóes europeias e para, através e acima dela, engrandecer Portugal.

Quanto ao Reino Lusitano como sendo "quasi cume da cabeça de Europa toda", a sua posição cimeira aparece explicitamente evidenciada, na maioria destes mapas, sob o nome latino de Lusitania, a preencher a haste frontal da coroa da jovem rainha Europa.

Não há dúvida de que o advérbio "quasi" não tem aqui um valor de aproximação espacial, mas mantém a sua semântica de origem latina, de sentido comparativo hipotético, "como se", "como que", "como quem diz", "por assim dizer", etc. É mesmo, a nosso ver, um dos latinismos mais evidentes d'Os Lusíadas. Com efeito, não se entende que Portugal pudesse estar localizado apenas quase no "cume da cabeça da Europa toda” quando ele ocupa de facto o absoluto extremo ocidental da Península Ibérica, "onde a Terra se acaba e o Mar começa", e, portanto, assume sem reservas a sua posição geográfica culminante em relação à Espanha e, consequentemente, à Europa inteira, na perspectiva do oriente para o ocidente. Ora, a imagem da figura feminina

\footnotetext{
${ }^{24}$ A identificaçấo desta figura com Carlos V - interpretação que, talvez na sua esteira, tem sido seguida por outros - parece-nos um anacronismo, porquanto o desenho e primeira inclusão deste mapa na Cosmografia de Münster data apenas a partir da edição de 1588, trinta anos depois da morte do Imperador e quase trinta e três após a sua abdicação da coroa do Sacro Império Romano-Germânico. Parece-nos que tal associação intempestiva tem que ver com o facto de Sebastiâo Münster ter dedicado a sua Cosmographia Vniversalis ao referido imperador numa longa carta-dedicatória que, desde a primeira ediçáo de 1544 - quando ele o era de facto -, viria a acompanhar as sucessivas reediçốes. Talvez tenha sido a mesma carta que levou alguns anotadores a considerar como sendo do mesmo Carlos V o retrato que a antecede a partir da edição de 1550, mas que não é senão a figura do próprio Sebastião Münster, de quando ele contava sessenta anos de idade, como a respectiva legenda esclarece: "S. M. Anno aetatis suae 60". Vd., por exemplo, as ediçôes latinas de Basileia de 1550, 1552 e 1572, nos exemplares existentes nas bibliotecas, respectivamente, da Universidade do Minho (cota: Res. 337 P.; e também, Nacional do Rio de Janeiro, cota 42.3.3.), Nacional de Lisboa (cota: Res. 2094) e Municipal de Viseu (cota: 11-VII-46); a edição italiana da mesma cidade suíça, de 1558 (exemplares da BNL, Res. 2095, e da Biblioteca Central da Marinha, R-Da-5-20), e a ediçáo alemã de 1598, também de Basileia, no exemplar da BNL, Res. 2096.
} 
dos mapas ginecomórficos confirma esta posição absoluta quando apresenta a palavra Lusitania gravada na parte superior da haste frontal da coroa daquela jovem rainha e lhe sobrepóe, ainda, o escudo de armas de Portugal, de modo a não deixar qualquer espaço superior vazio. Objectivamente, portanto, o Reino Lusitano está ali realmente colocado no topo de toda a Europa física.

MAPA XIV: pormenor do mapa ginecomórfico

de Heinrich Bünting (cf. Mapa VIII), em posição sul-norte e com a Lusitânia no cume da cabeça.

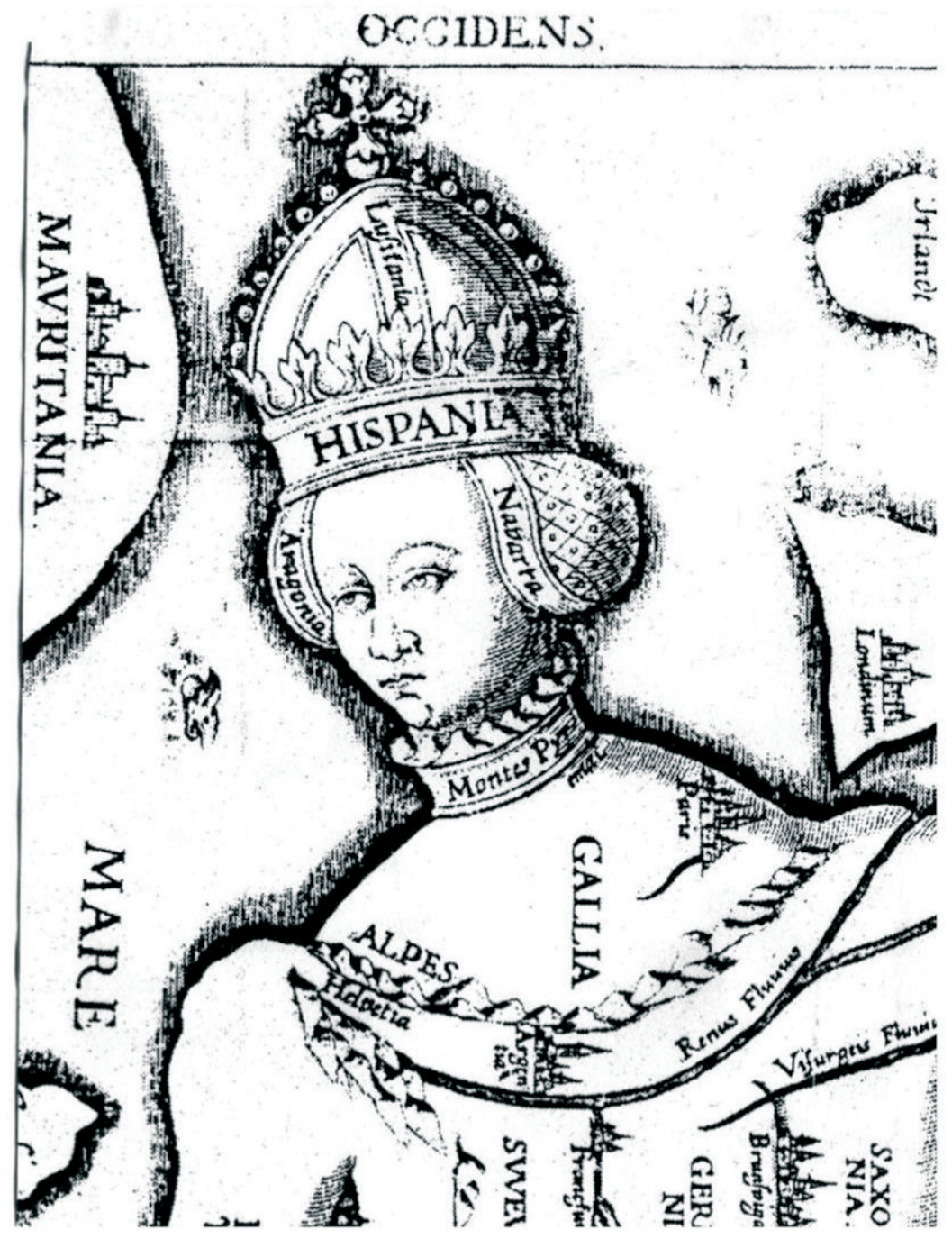

A nobre Hespanha, como cabeça ali de Europa toda.

Quási cume da cabeça de Europa toda, o Reino Lusitano. 
MAPA XV: pormenor do mapa de Iohann Putsch (cf. Mapa XII), com o nome da Lusitânia distribuído na haste da coroa da "Europa Rainha".

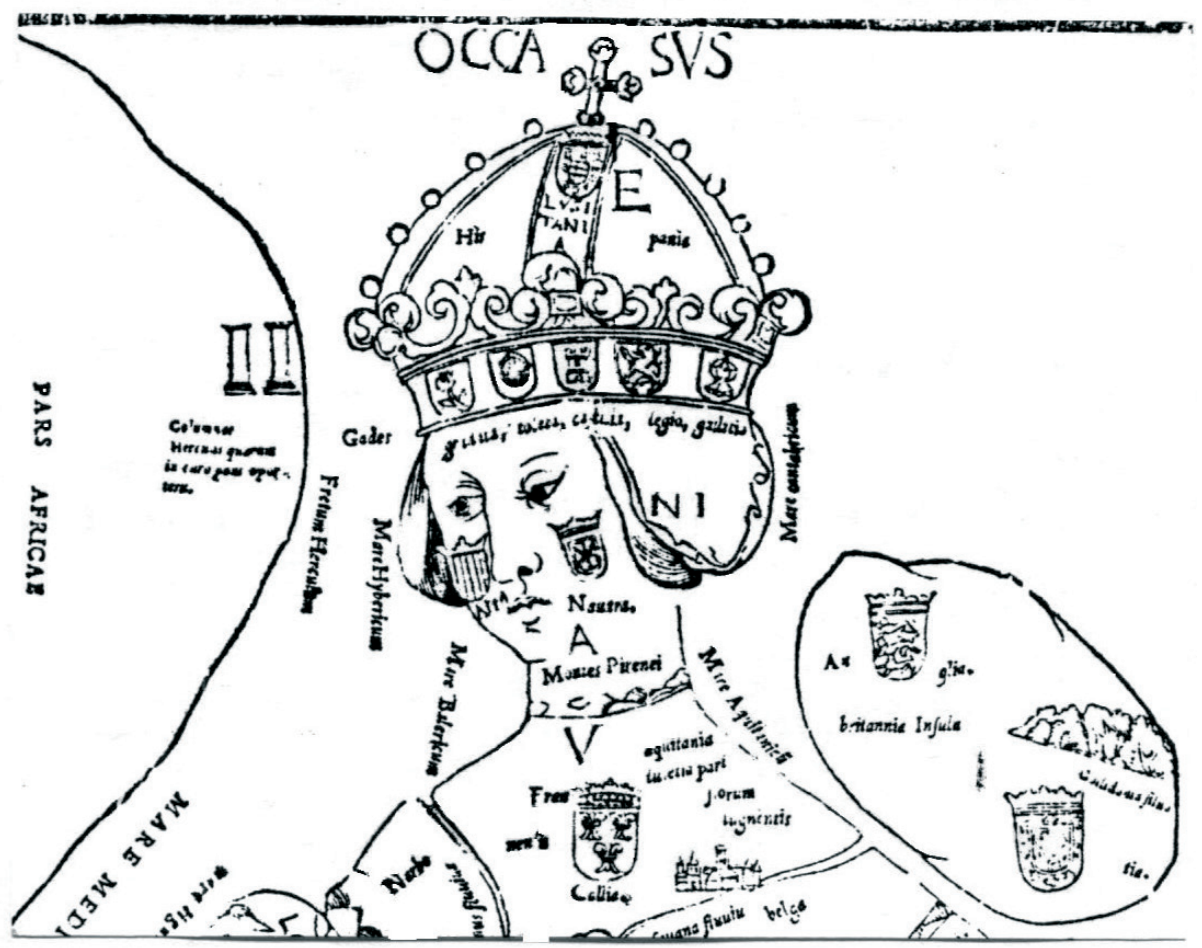

Assim, o valor comparativo imposto pelo advérbio "quasi” só pode ser entendido no sentido translato, simbólico e ideológico da preeminência europeia de Portugal, contribuindo deste modo para a função retórica e épica de toda a descrição camoniana da Europa.

De resto, é evidente que um dos objectivos da longa fala de Vasco da Gama perante o rei de Melinde é o de engrandecer a ditosa pátria sua amada e a nobre estirpe da gente lusitana, a fim de impressionar aquele rei e o seu povo e de captar a sua benevolência e o bom acolhimento para os portugueses naquelas partes do Oriente. O carácter retórico deste discurso é o mesmo da descrição das figuras das bandeiras da capitaina por Paulo da Gama perante o Catual, no canto VIII. É também a mesma estrutura retórica que está presente na descrição da "Máquina do Mundo", em que a história portuguesa é exaltada pela boca de Tétis, embora não já para cativar desvairadas gentes nativas, mas para a função épica geral do poema. Nestes dois últimos casos, o discurso assume força e características especiais, pela explícita presença icónica da imagem plástica, que faz deles um estremado exemplo do discurso ecfrástico da oratória demonstrativa, como muito bem acentua Fernando Gil no já citado livro das Viagens do Olhar ${ }^{25}$. No caso da

${ }^{25}$ Cf. idem, ibidem e p. 87 sqq. Vd. supra, final da nota 2. 
descrição da Europa, terá sido, a nosso ver, o mapa ginecomórfico de Johann Putsch a desempenhar esse papel, ainda que de forma não explicitamente denunciada.

Em conclusão, a linguagem antropográfica da descrição camoniana da Europa, associada ao seu estilo visualista, e corresponsável por ele, e a analogia que este oferece com o que se passa na explicação das bandeiras da nau capitaina por Paulo da Gama, no canto VIII, e com a apresentação da Máquina do Mundo, do Canto X, nas quais o mesmo carácter visual é reforçado pela expressa presença e recurso a meios plásticos picturais e arquitectónicos, reconfirmam-nos na convicção de que Camôes, também ao descrever a Europa, tinha presente uma imagem física: o desenho cartográfico de alguma destas figuraçóes ginecomórficas, ou de outras semelhantes. A écfrase da descrição camoniana da Europa tem aqui, a nosso ver, o mapa e a representação material que lhe faltavam. 